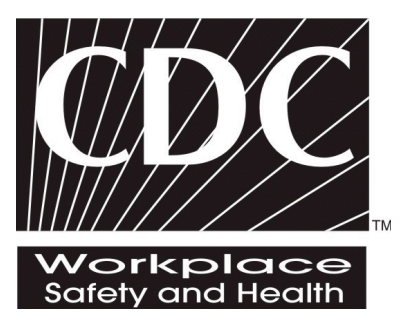

\title{
REPORT OF INVESTIGATIONS 9665
}

\section{TEMPERATURE CORRECTIONS TO EARTH PRESSURE CELLS EMBEDDED IN CEMENTED BACKFILL}

D.R. Tesarik, J.B. Seymour, T.J. Williams, L.A. Martin, and F.M. Jones

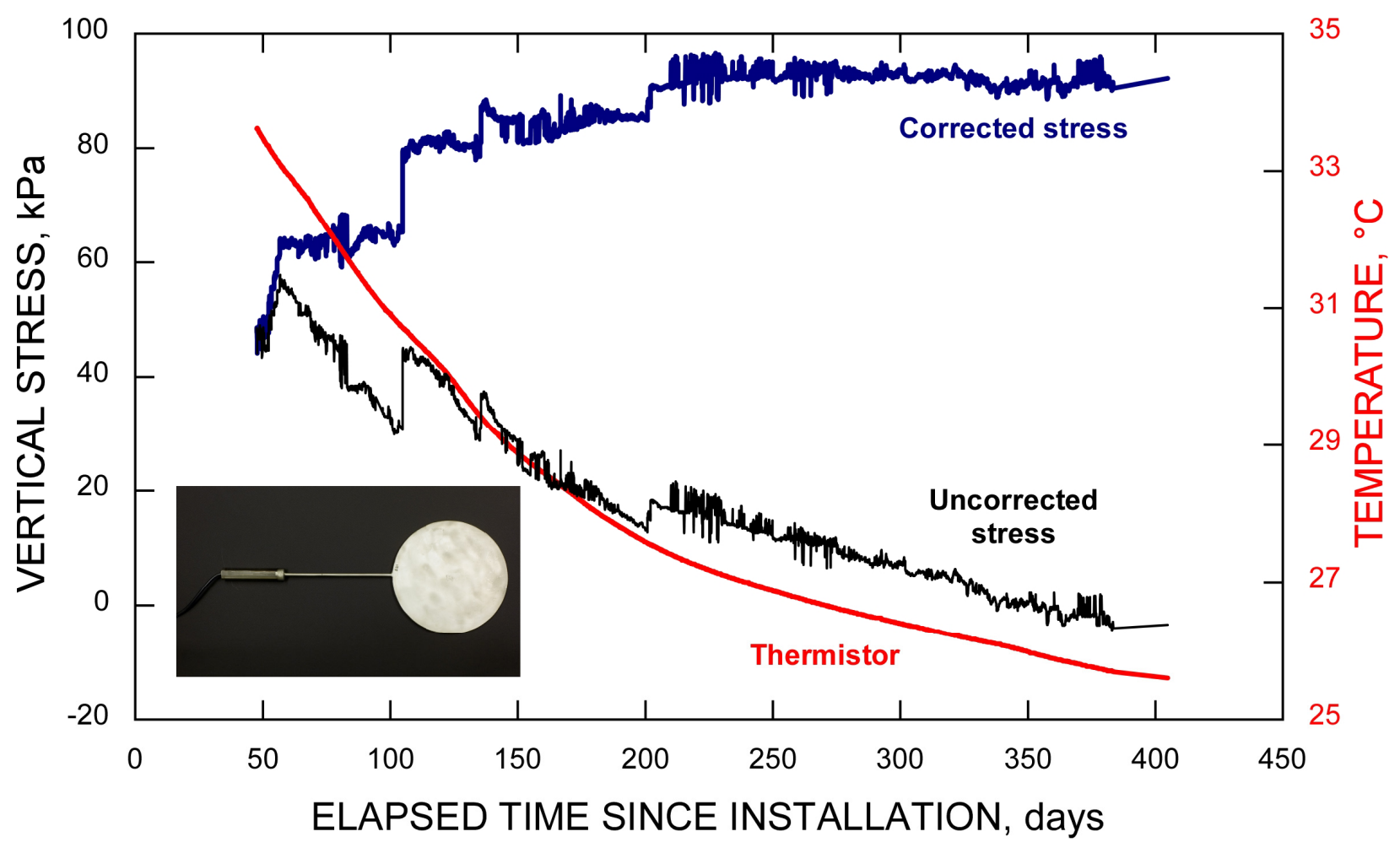

Department of Health and Human Services Centers for Disease Control and Prevention National Institute for Occupational Safety and Health 
Cover: Simplified graph showing differences in stress when readings are and are not corrected for temperature. Inset shows bioxial stressmeter. 


\section{REPORT OF INVESTIGATIONS 9665}

\section{TEMPERATURE CORRECTIONS TO EARTH PRESSURE CELLS EMBEDDED IN CEMENTED BACKFILL}

D.R. Tesarik, J.B. Seymour, T.J. Williams, L.A. Martin, and F.M. Jones

U.S. DEPARTMENT OF HEALTH AND HUMAN SERVICES

Centers for Disease Control and Prevention

National Institute for Occupational Sofety and Health

Spokone Research Loboratory, Spokone, WA

April 2006 


\section{ORDERING INFORMATION}

Copies of National Institute for Occupational Safety and Health (NIOSH) documents and information about occupational safety and health are available from

NIOSH-Publications Dissemination 4676 Columbia Parkway

Cincinnati, OH 45226-1998

FAX:

513-533-8573

Telephone: 1-800-35-NIOSH

e-mail pubstaft@,cdc.gov

Web site: www.cdc.gov/niosh

This document is in the public domain and may be freely copied or reprinted.

\section{Disclaimer:}

The findings and conclusions in this paper are those of the authors and do not necessarily represent the views of the National Institute for Occupational Safety and Health (NIOSH), nor does mention of any company or product constitute endorsement by NIOSH.

DHHS (NIOSH) Publication No. 2006-103 


\section{TABLE OF CONTENTS}

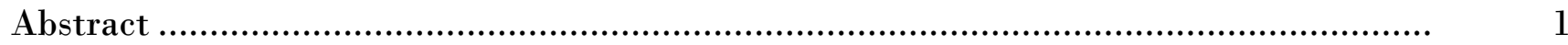

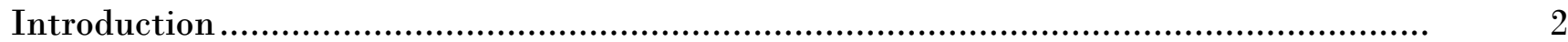

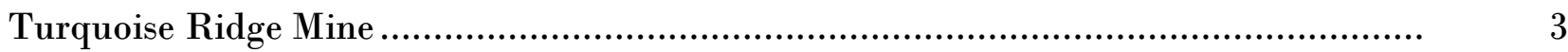

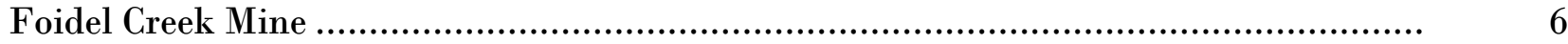

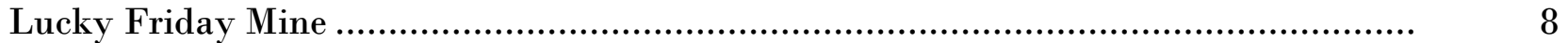

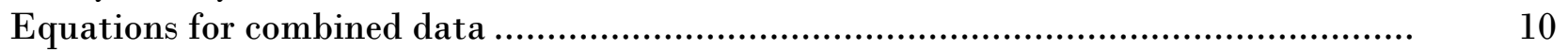

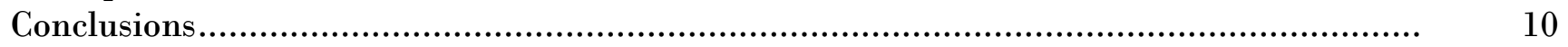

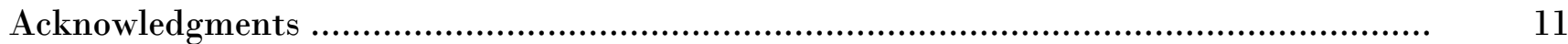

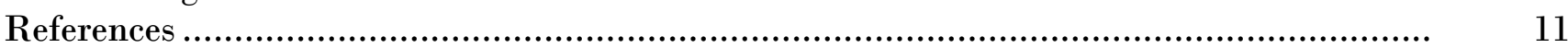

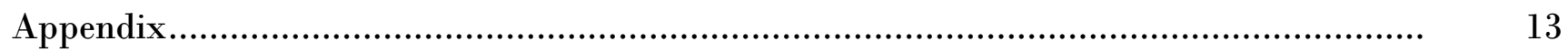

\section{TABLE}

1. Correction factors for nonmining periods

\section{LIST OF FIGURES}

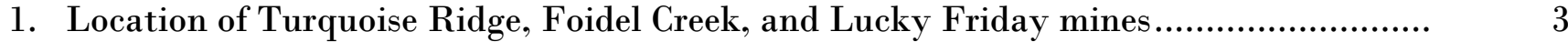

2. Elevation and plan view of backfill span test site at Turquoise Ridge Mine................ 4

3. Plan view of instrumented section of eight-right longwall panel, gateroads, and

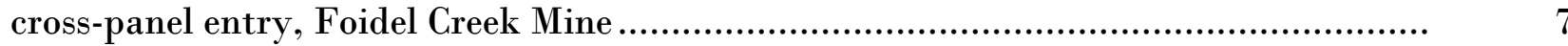

4. Plan view of 5660-05-level intersection and instrument locations at Lucky Friday Mine. 


\section{UNIT OF MEASURE ABBREVIATIONS USED IN THIS REPORT}

$\begin{array}{llll}\mathrm{cm} & \text { centimeter } & \text { in } & \text { inch } \\ \mathrm{kg} / \mathrm{m}^{3} & \text { kilogram per cubic meter } & \mathrm{ft} & \text { foot } \\ \mathrm{km} & \text { kilometer } & \mathrm{ft} / \text { day } & \text { foot per day } \\ \mathrm{kN} & \text { kilonewton } & \mathrm{lb} & \text { pound } \\ \mathrm{kPa} & \text { kilopascal } & \mathrm{lb} / \mathrm{ft}^{3} & \text { pound per cubic foot } \\ \mathrm{m} & \text { meter } & \mathrm{psi} & \text { pound per square inch } \\ \mathrm{m} / \mathrm{day} & \text { meter per day } & { }^{\circ} \mathrm{F} & \text { degree Fahrenheit } \\ \mathrm{mm} & \text { millimeter } & \% & \text { percent } \\ \mathrm{MPa} & \text { megapascal } & \circ & \text { degree } \\ \mathrm{Pa} & \text { pascal } & & \\ { }^{\circ} \mathrm{C} & \text { degree Celsius } & & \end{array}$




\title{
TEMPERATURE CORRECTIONS TO EARTH PRESSURE CELUS EMBEDDED IN CEMENTED BACKFILL'
}

\author{
D.R. Tesarik, J.B. Seymour, T.J. Williams, L.A. Martin, and F.M. Jones
}

\section{ABSTRACT}

Determining backfill stress is an important part of evaluating mine safety, whether personnel are working in proximity to backfill or in other areas of the mine where backfill is an integral part of regional support. To assist in determining stress in backfill more accurately, researchers from the Spokane Research Laboratory of the National Institute for Occupational Safety and Health, Placer Dome, Inc. (Turquoise Ridge Mine), Peabody Energy Co. (Foidel Creek Mine), and Hecla Mining Co. (Lucky Friday Mine) used temperature readings recorded by thermistors to correct for the influence of temperature on stress data. These thermistors were positioned in the stems of earth pressure cells installed in backfill. Corrections were then calculated and compared using four different methods: polynomial equations fit to temperature-versus-stress plots before the pressure cells were loaded by overburden, a factor provided by the manufacturer, a theoretically derived factor, and a linear correction factor based on information collected during periods when no mining was taking place.

To evaluate the accuracy of these methods, corrected stresses were calculated using each method and results compared to cumulative stresses caused by blasting at one of the mines. Results indicated that only a small percentage of the temperature effect on stress was corrected using the factor from the manufacturer because that factor accounted for only the pressure transducer and not the entire instrument body. Stresses adjusted with a linear correction factor based on information collected during periods when no mining was taking place were the most accurate. Stresses recorded at two other mines were corrected using the theoretical method and the polynomial equations method; the two methods produced similar results. For some time intervals, the results were identical.

\footnotetext{
${ }^{1}$ The findings and conclusions in this paper are those of the authors and do not necessarily represent the views of the National Institute for Occupational Safety and Health (NIOSH).
} 


\section{INTRODUCTION}

Earth pressure cells are generally used in underground mines to measure stresses in the backfill. Because a number of factors affect the accuracy of the cells, such as the ratio of backfill modulus to cell modulus, cell geometry, installation procedures, nonuniform or point loading, and temperature, the cells cannot be relied upon for precise measurements (Dunicliff and Green, 1998). However, when the earth pressure cells are used in conjunction with instruments installed in the host rock, they can provide valuable information on mining-induced stress transfer (Seymour et al., 1998; Tesarik et al., 1989).

Temperature changes can significantly affect earth pressure cell readings, but the correction factor supplied by the manufacturer applies only to the transducer itself and not to the whole cell. Laboratory tests have shown that, without accounting for temperature in the entire earth pressure cell assembly, the temperature effect can be largely underestimated (Daigle and Zhao, 2003). These tests also have indicated that correction equations, which express temperature-induced stress as a function of temperature, are linear when the cell is not loaded, but nonlinear when the cell is under a constant load. For safety reasons, correcting for the effects of temperature is especially important if the magnitude of the applied stresses in the mine backfill or the shotcrete is close to the strength of the backfill materials. In addition, the influence of temperature on earth pressure cell readings could mask other factors, such as creep in the backfill.

The earth pressure cells used in this study consisted of two 22.9 -cm- (9-in) diameter, circular stainless steel plates welded together around their edges with the space between the plates filled with oil. A 21.6cm- (8.5-in-) long, high-pressure stainless steel tube connected the cavity to a vibrating wire or semiconductor strain gauge pressure transducer installed in a cylindrical housing. A thermistor was also positioned in this housing.

Backfill pressure acting on the cell is balanced by an equal pressure induced in the oil; this pressure is converted to an electrical signal by the vibrating wire and a coil mechanism in the housing. The maximum working capacity for the earth pressure cells is $6.9 \mathrm{MPa}(1,000 \mathrm{psi})$. Earth pressure cells installed at the Turquoise Ridge and Foidel Creek mines were equipped with vibrating wire transducers having an accuracy of $17.2 \mathrm{kPa}(2.5 \mathrm{psi})$ and a resolution equal to $6.9 \mathrm{kPa}(1 \mathrm{psi})$. Semiconductor strain gauges with an accuracy of $70 \mathrm{kPa}(10 \mathrm{psi})$ and infinite resolution were used in the cells at the Lucky Friday Mine (Geokon, 1996). Electrical signals from the thermistor and pressure transducer were transmitted to a Campbell Scientific ${ }^{2}$ datalogger by a four-conductor, shielded, direct-burial cable.

Plots of measured stress and temperature versus elapsed time showed similar trends in stress and temperature, indicating that temperature likely influenced stress. To facilitate interpretation and improve the accuracy of the stress readings recorded by the earth pressure cells embedded in the backfill, second-degree polynomial equations were fit to stress-versus-temperature data recorded before mining-induced stresses loaded the cells. These equations were then used to correct the stress readings. A theoretical correction factor (Sellers, 2000), the manufacturer's correction factor, and correction factors calculated from plots of stress versus temperature collected during nonmining periods were also applied to the stress data. The accuracy of these methods was evaluated by comparing maximum corrected stress to cumulative stress caused by blasting at the Turquoise Ridge Mine.

\footnotetext{
${ }^{2}$ Mention of specific products or manufacturers does not constitute endorsement by the National Institute for Occupational Safety and Health.
} 
The Turquoise Ridge Mine, owned by Placer Dome, Inc., ${ }^{3}$ Vancouver, BC, is a gold deposit $45 \mathrm{~km}$ (28 miles) northeast of Golconda, NV (figure 1). Mineralization took place at depths between 427 and $671 \mathrm{~m}$ (1,400 and 2,200 $\mathrm{ft})$ along the intersection of northwest-northeast-trending shear zones (Berentsen et al., 1996). Drift-and-fill mining is used because of the poor ground conditions commonly encountered. To determine if a new mining method could improve productivity and reduce the exposure of mine personnel to ground fall hazards, a backfill span was tested $390 \mathrm{~m}(1,280 \mathrm{ft})$ below the surface. A backfill cap consisting of six adjacent $3.8-\mathrm{m}-(12.5-\mathrm{ft})$ wide, $4.6-\mathrm{m}$ - (15$\mathrm{ft})$ high, and 30.5-m- (100-ft) long cemented rockfill drifts was undercut by mining two outside drifts $4.3 \mathrm{~m} \mathrm{(14 \textrm {ft } )}$ wide and $4.6 \mathrm{~m}$ (15 ft) high. This left a central pillar that was retreated in sections to produce a room $13.7 \mathrm{~m}(45 \mathrm{ft})$ wide and $30.5 \mathrm{~m}$ (100 ft) long beneath the backfill (figure $2)$.

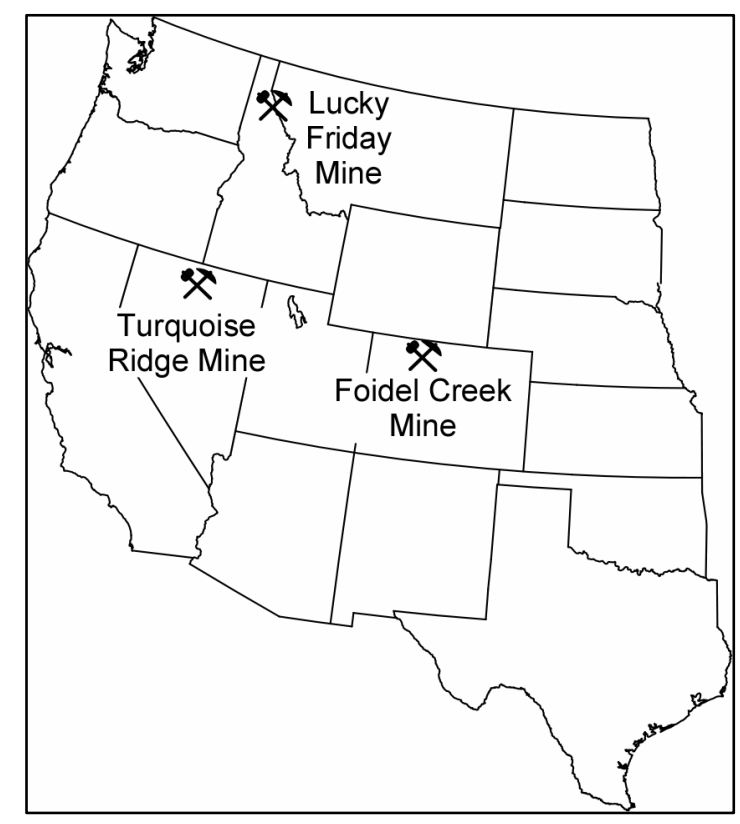

Figure 1.-Location of Turquoise Ridge, Foidel Creek, and Lucky Friday mines.

Instruments were placed in both the host rock and the backfill to monitor the safety of the backfill cap and to document stress redistribution during construction and subsequent undercutting of the cap (figure 2). A two-dimensional numerical model of the test stopes was used to estimate backfill stress and select the range for the earth pressure cells. Because overburden stresses were redistributed to only two abutments in the two-dimensional model and the deformation modulus input into the model was too low, predicted backfill stresses were much larger than those subsequently measured. It was difficult to determine mining-induced stress changes in the backfill accurately because of the significant effect of temperature on instrument readings. For example, after the instruments were shotcreted to secure them in place and before backfill was placed over them, a temperature rise in an earth pressure cell, from $28^{\circ} \mathrm{C}$ to $60^{\circ} \mathrm{C}\left(83^{\circ} \mathrm{F}\right.$ to $\left.140^{\circ} \mathrm{F}\right)$, caused by heat of hydration resulted in a stress increase of $820 \mathrm{kPa}(119 \mathrm{psi})$. Nearly all of this stress can be attributed to the change in temperature because the shotcrete that covered the instruments was only several centimeters thick.

Before the earth pressure cells were installed near mid-length of each of the four drifts, cells 1 and 2 were cast in forms using minus $1.9-\mathrm{cm}(0.75$-in) screened backfill to help prevent point loading. The other two cells were case in the mine's grout mix because backfill was not available when they were cast. After the forms were removed, the cells wer placed on a 1.5- to 2.1-m- (5- to 7-ft) high bench formed in recently placed backfill using a load-haul-dump machine (LHD). Shotcrete was sprayed over the instruments and their cables to maintain orientation and protect them from mining equipment when the remainder of the drift was backfilled.

\footnotetext{
${ }^{3}$ Formerly owned by Getchell Gold Corp.
} 

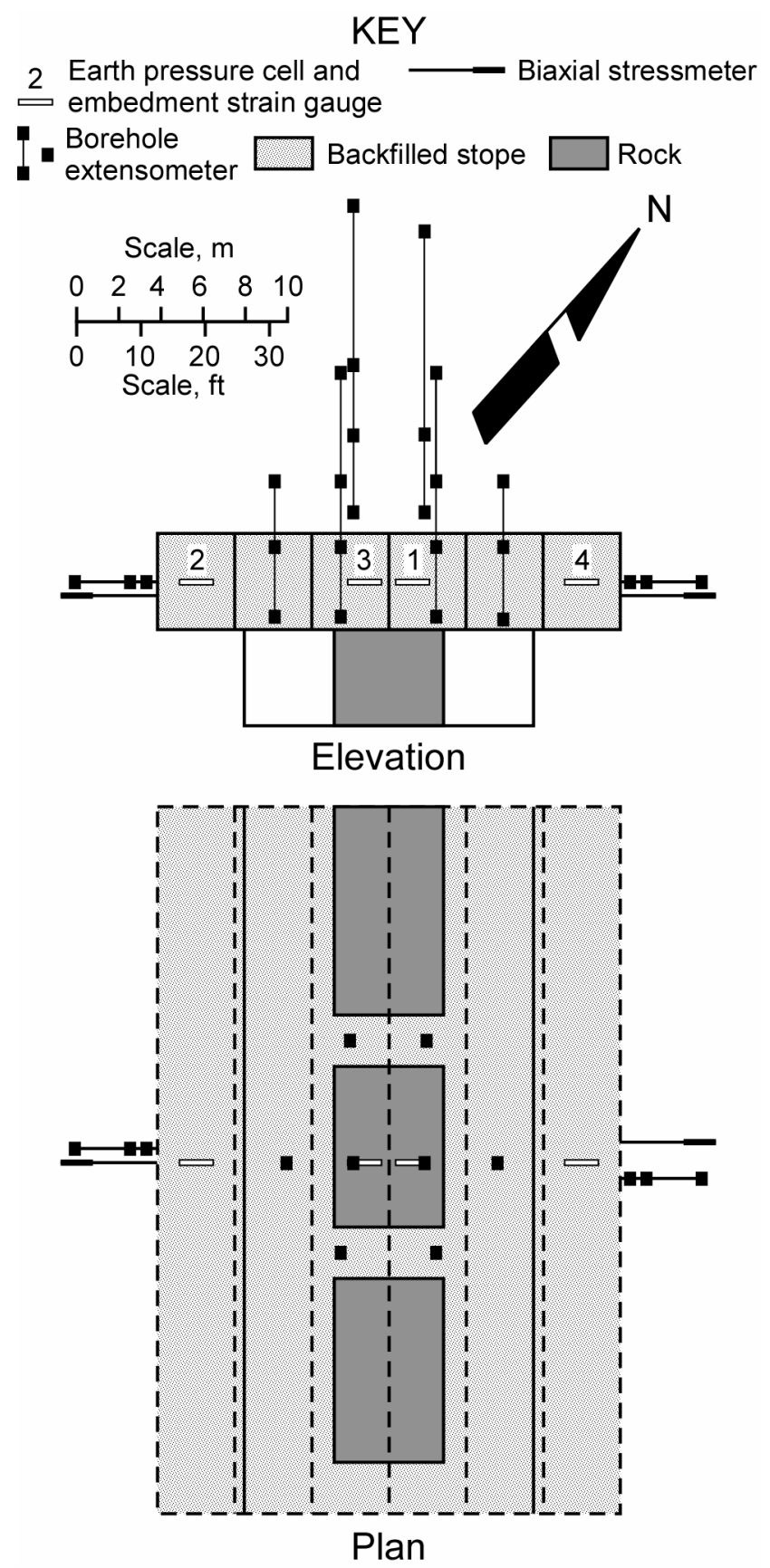

The manufacturer provides an equation (equation 1) and a correction factor to compensate for the effect of temperature on the vibrating wire transducer, which is positioned in the transducer housing of each earth pressure cell (Geokon, 1996). These correction factors were $0.29,0.32,1.08$, and $0.49 \mathrm{kPa} /{ }^{\circ} \mathrm{C}\left(0.023,0.026,0.087\right.$, and $\left.0.039 \mathrm{psi} /{ }^{\circ} \mathrm{F}\right)$ for earth pressure cells 1 through 4 , respectively (figure 2). Because these correction factors do not account for the effect of temperature on the body of the earth pressure cell, the correction was small relative to the stress readings. For clarity, the stressversus-time plot corrected with the manufacturer's equation is included only in figure Al (appendix A). Readings were not recorded by the datalogger before the start of cut 3 because of a programming error.

$$
\sigma_{\mathrm{c}}=\sigma-\mathrm{C} \times\left(\mathrm{T}_{\mathrm{i}}-\mathrm{T}_{0}\right),
$$

where

$$
\begin{aligned}
\sigma_{\mathrm{c}} & =\text { corrected stress, } \mathrm{kPa}(\mathrm{psi}), \\
\sigma & =\text { measured stress, } \mathrm{kPa}(\mathrm{psi}), \\
\mathrm{C} & =\text { correction factor, } \mathrm{kPa} /{ }^{\circ} \mathrm{C}\left(\mathrm{psi} /{ }^{\circ} \mathrm{F}\right), \\
\mathrm{T}_{\mathrm{i}} & =\text { current temperature, },{ }^{\circ} \mathrm{C}\left({ }^{\circ} \mathrm{F}\right),
\end{aligned}
$$

and

The magnitude of the thermal effect on an earth pressure cell can be estimated using the geometry and material properties of the cell and the elastic modulus of the surrounding medium (Sellers, 2000) (equation 2). The laboratory-determined modulus equal to $2,264.238 \times 10^{6} \mathrm{~Pa}(328,400 \mathrm{psi})$ was used in equation 2 because the backfill was screened and packed tightly around the earth pressure cells. The earth pressure cells had a radius of $114.3 \mathrm{~mm}$ ( $4.5 \mathrm{in})$ and were filled with a $0.51-\mathrm{mm}-(0.02$-in-) thick film of oil having a coefficient of thermal expansion equal to $700 \times 10^{-6} /{ }^{\circ} \mathrm{C}\left(388.9 \times 10^{-6 /}{ }^{\circ} \mathrm{F}\right)$. Using these values in equation 2 yields a correction factor equal to $10.6 \mathrm{kPa} /{ }^{\circ} \mathrm{C}\left(0.851 \mathrm{psi} /{ }^{\circ} \mathrm{F}\right)$.

$$
\mathrm{C}=1.5 \times \mathrm{E} \times \mathrm{K} \times \mathrm{D} / \mathrm{R} \text {, }
$$

where $\quad \mathrm{C}=$ correction factor, $\mathrm{Pa} /{ }^{\circ} \mathrm{C}\left(\mathrm{psi} /{ }^{\circ} \mathrm{F}\right)$,

$\mathrm{E} \quad=$ elastic modulus of the medium, $\mathrm{Pa}(\mathrm{psi})$,

$\mathrm{K}=$ coefficient of thermal expansion of liquid film encased in earth pressure cell, $1 /{ }^{\circ} \mathrm{C}\left(1 /{ }^{\circ} \mathrm{F}\right)$,

$\mathrm{D}=$ thickness of liquid film in earth pressure cell, $\mathbf{m m}$ (in),

and

$\mathbf{R}=$ radius of earth pressure cell, $\mathbf{m m}$ (in). 
The theoretically determined correction factor was applied only to stresses recorded by earth pressure cells 1 and 2 because the modulus of the grout surrounding cells 3 and 4 was not determined. If the stress data are corrected using the temperature at the time of installation, temperature-induced negative stresses are generated (figures A1 and A2). In laboratory experiments, Daigle and Zhao (2003) also recorded negative temperature-induced stresses. However, if stress corrections are calculated as of the first day that the datalogger takes readings on a 2 -hr basis and using an initial stress equal to $48 \mathrm{kPa}$ (7 psi), which is the stress exerted by $2.3 \mathrm{~m}(7.5 \mathrm{ft})$ of backfill with a specific weight of $2,146 \mathrm{~kg} / \mathrm{m}^{3}(134$ $\mathrm{lb} / \mathrm{ft}^{3}$ ), then the corrected stresses remain positive (figures A3 and A4). The overburden load on the cells was assumed to be zero when the datalogger became functional because drifts 3 and 6 had not been mined at this time, and the rock in these drifts and the abutments were likely to carry most of the mining-induced overburden stress. Temperature-induced stress loss between mining events was reduced in the stresses for earth pressure cell 1 (figure A3) and nearly eliminated in cell 2 (figure A4).

Temperature and stress data for earth pressure cells 3 and 4 (recorded after the cells were covered with a thin layer of shotcrete, but before backfill was placed over them) were also used to correct stress readings. The stress paths are different for each cell, and the heating phases are not identical to the cooling phases, which implies a hysteresis effect. Because plots of temperature versus stress exhibited a nonlinear relationship, polynomial functions were fit to these data (equation 3) (figures A5 and A6). Temperatures less than $29^{\circ} \mathrm{C}\left(84^{\circ} \mathrm{F}\right)$ for earth pressure cell 4 were not used in the regression analysis because of an unexplainable change in stress at about $27^{\circ} \mathrm{C}\left(80^{\circ} \mathrm{F}\right)$ without a significant change in temperature.

$$
\sigma_{\mathrm{c}} \quad=\sigma-\mathrm{A}+\mathrm{B} \times\left(\mathrm{T}_{\mathrm{i}}\right)+\mathrm{C} \times\left(\mathrm{T}_{\mathrm{i}}\right)^{2}+\mathrm{D} \times\left(\mathrm{T}_{\mathrm{i}}\right)^{3},
$$

where $\quad \sigma_{\mathrm{c}} \quad=$ corrected stress, $\mathrm{kPa}(\mathrm{psi})$,

$\sigma \quad=$ measured stress, $\mathrm{kPa}(\mathrm{psi})$,

$\mathrm{A}, \mathrm{B}, \mathrm{C}$, and $\mathrm{D}=$ constants determined using regression analysis,

and $\quad \mathrm{T}_{\mathrm{i}}=$ current temperature, ${ }^{\circ} \mathrm{C}\left({ }^{\circ} \mathrm{F}\right)$.

Daigle and Zhao (2003) reported a linear relationship between temperature-induced stress and temperature when cells were not loaded; however, the maximum temperature in their experiment was $30^{\circ} \mathrm{C}\left(86^{\circ} \mathrm{F}\right)$, and the maximum temperature range for the earth pressure cells installed at the Turquoise Ridge Mine was $37^{\circ} \mathrm{C}$ to $61^{\circ} \mathrm{C}\left(98{ }^{\circ} \mathrm{F}\right.$ to $\left.141{ }^{\circ} \mathrm{F}\right)$. When applied to recorded stresses, the polynomial equations reduced the effect of the initial temperature spike in both earth pressure cells, but produced negative stresses and did not eliminate the effects of decreasing temperature (figures A7 through A10).

Temperature correction factors for equation 1 were also obtained by calculating the slope of the line produced by plotting vertical stress against temperature during nonmining periods after the earth pressure cells were covered with backfill (figures A11 through A14) (table 1). The average of these values for each pressure cell was used as the correction factor. Unlike the three previous methods, applying the average correction factor for each cell to stress readings nearly eliminated the effect of temperature on stress for most of the nonmining intervals (figures A1 through A4 and A7 through A10). This is particularly evident for the 204 days following the removal of pillars 2 and 3. 
Table 1.-Correction factors for nonmining periods, kilopascals per degree Celsius (pounds per square inch per degree Fahrenheit)

\begin{tabular}{|c|c|c|c|c|}
\hline & EPC 1 & EPC 2 & EPC 3 & EPC 4 \\
\hline Nonmining period & & & & \\
\hline Backfilling drift 2 & $\mathrm{NA}^{1}$ & NA & NA & \\
\hline Backfilling drift 3 & $22.5(1.81)$ & $8.9(0.72)$ & $\begin{array}{l}27.8,18.6,7.7(2.24 \\
1.50,0.62)^{2}\end{array}$ & \\
\hline Between mining cuts 7 and 9 & NA & NA & NA & \\
\hline $\begin{array}{l}\text { Between mining cut } 9 \text { and } \\
\text { crosscut } 1\end{array}$ & NA & NA & NA & $4.3(1.13)$ \\
\hline $\begin{array}{l}\text { Between mining crosscuts } 2 \\
\text { and } 3\end{array}$ & NA & NA & NA & NA \\
\hline $\begin{array}{l}\text { Between mining crosscut } 3 \text { and } \\
\text { pillar } 1\end{array}$ & $22.6(1.82)$ & $8.7(1.26)$ & $21.8,9.1(1.76,0.73)$ & $11.7(0.94)$ \\
\hline After mining pillar 3 & $21.1(1.70)$ & $11.0(0.89)$ & $14.6(1.18)$ & $31.5,21.0(2.54,1.69)$ \\
\hline Average & $22.1(1.78)$ & $11.9(0.96)$ & $16.6(1.34)$ & $19.6(1.58)$ \\
\hline
\end{tabular}

The total stress change attributable to mining alone in four backfilled stopes was calculated by summing observable individual stress changes during mining periods by using plots of stress versus time (figure A15). These sums were used to evaluate the accuracy of the correction methods on the last day data were recorded (figures A3 through A7). Data from earth pressure cells 1 and 2 were not compared before the data were reinitialized because stresses were negative. For the reinitialized data, the final stresses corrected with factors from the nonmining periods were closer to the sum of the individual stresses than was the final stress corrected using the theoretical method. This suggests that reinitializing the data was reasonable and that combining techniques helps interpret seemingly meaningless data. The final corrected stresses for earth pressure cells 3 and 4 were closer to the sum of the individual stresses when correction factors from nonmining periods were used as opposed to using the polynomial equation.

\section{FOIDEL CREEK MINE}

The Foidel Creek Mine, owned by Peabody Energy Co., ${ }^{4}$ St. Louis, MO, is near Oak Creek, CO, approximately $32 \mathrm{~km}$ (20 miles) southwest of Steamboat Springs, CO (figure 1). The mine uses state-ofthe-art longwall equipment to mine low-sulfur, high-quality bituminous coal from a 2.6- to 3-m- (8.5- to 10 -ft) thick coal seam at a depth of about $396 \mathrm{~m}(1,300 \mathrm{ft})$. Because this high-capacity longwall system advances at an average rate of $152 \mathrm{~m} /$ day (400 ft/day) (Carter, 1996), three parallel 6-m- (20-ft) wide entries were driven across a $248-\mathrm{m}-(815-\mathrm{ft})$ wide by $5,486-\mathrm{m}-(18,000-\mathrm{ft})$ long longwall panel. The crosspanel entries provided access for development of the gateroad entries as well as escapeways for miners.

To maintain entry and longwall stability during subsequent mining of the panel and to eliminate the need for a longwall face change, Cyprus Twentymile Coal Co., the mine operator at the time of this research, decided to support the in-panel entries with an air-entrained mixture of fly ash, $10 \%$ cement, and a foaming agent. Instruments were installed in the longwall panel, cross-panel pillars, mine roof, and backfill to monitor and evaluate the stability of the panel as the longwall advanced through the backfilled entries (figure 3). Five earth pressure cells designed to measure a maximum stress equal to $6.89 \mathrm{MPa}(1,000 \mathrm{psi})$ and equipped with thermistors were placed approximately $2.3 \mathrm{~m}(7.5 \mathrm{ft})$ from the

\footnotetext{
${ }^{4}$ Formerly owned by Cyprus Twentymile Coal Co.
} 


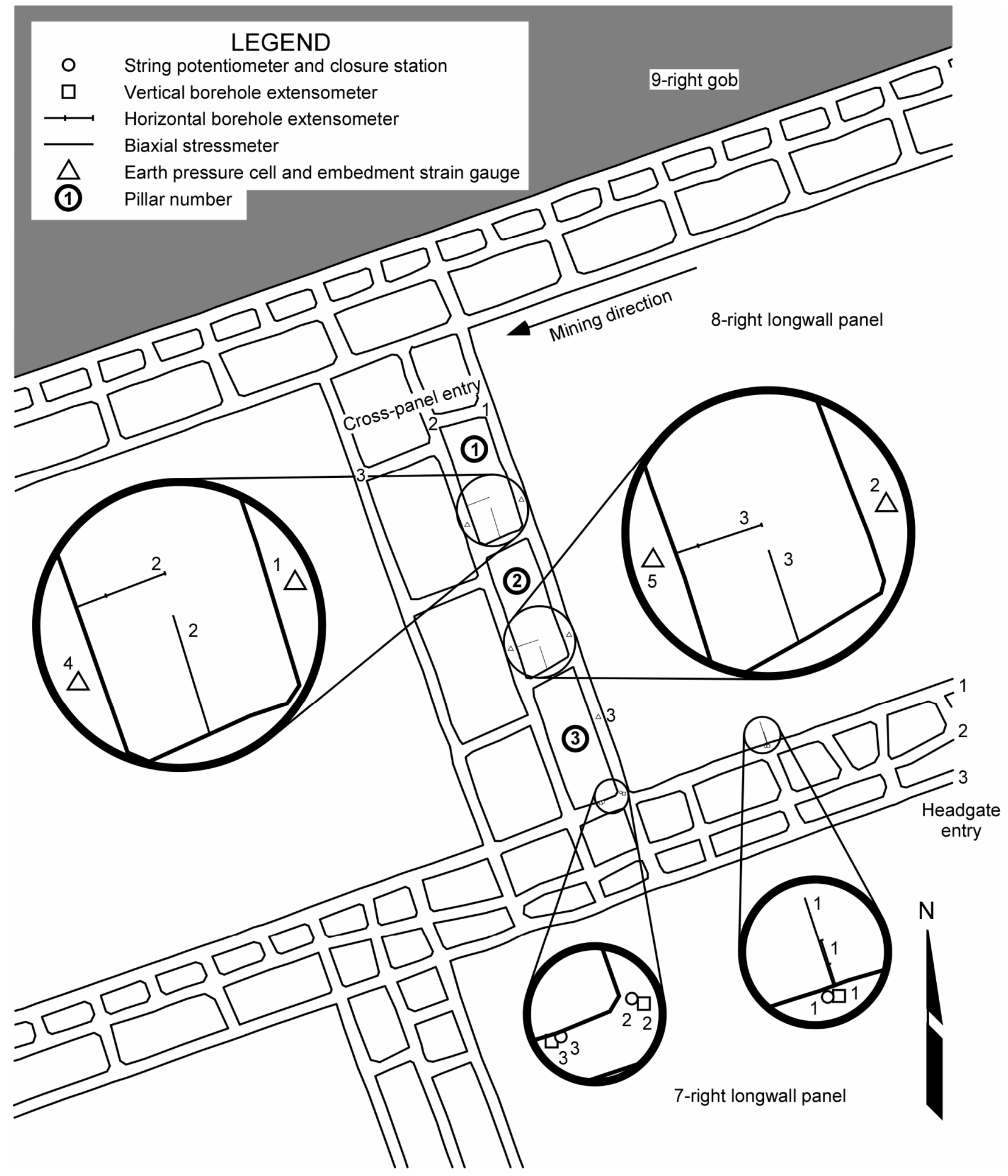

Figure 3.-Plan view of instrumented section at eight-right longwall panel, gateroads, and cross-panel entry, Foidel Creek Mine.

mine roof (Seymour et al., 1988). The high range for the earth pressure cells was chosen because of the large overburden depth and to ensure that their maximum working stress would not be exceeded. To prevent flowing backfill from moving the instrument, each pressure cell was suspended in a plywood frame with wire, muck was placed around the frame, and backfill was shoveled over the instrument. Four of these instruments provided reliable data until the longwall shearer mined through them. 
Second-order polynomial functions were fit to temperature-induced vertical stress-versustemperature data for the period from installation of the cell in the backfill to final filling of the drift (figures A16 through A19). Temperature-induced stress was estimated for each reading in this time period by subtracting the weight of the backfill from each recorded stress value (equation 4). The calculated maximum stress on the earth pressure cells caused by the weight of the backfill was $44.8 \mathrm{kPa}$ ( $6.5 \mathrm{psi})$, or $0.65 \%$ of the maximum stress that the cells were designed to measure. It was assumed that the entries were filled at a constant rate. The response to temperature was nearly the same for each earth pressure cell (figure A20).

$$
\sigma_{\mathrm{bf}} \quad=\gamma \times \mathbf{h} \times \Delta \mathrm{t} / \mathrm{T}
$$

where $\quad \sigma_{\mathrm{bf}}=$ stress from the weight of the backfill at time $\mathrm{t}_{\mathrm{i}}, \mathrm{kPa}(\mathrm{psi})$,

$\gamma \quad=$ specific weight of the backfill, $1,488 \mathrm{~kg} / \mathrm{m}^{3}\left(92.9 \mathrm{lb} / \mathrm{ft}^{3}\right)$,

$\mathrm{h}=$ height of the backfill above earth pressure cell at time $\mathrm{t}_{\mathrm{i}}, \mathbf{m}(\mathrm{ft})$,

$\Delta t=t_{i}-t_{0}=$ elapsed time since earth pressure cell was installed at time $t_{0}$, days,

and $\mathrm{T}=$ time between installation of earth pressure cell and completion of backfilling, days.

Corrected stresses were much lower than measured stresses (figures A21 through A24), illustrating the importance of accounting for the influence of temperature. With a laboratory-obtained deformation modulus for the backfill equal to 586.1 MPa (85,000 psi) (Seymour et al., 1998), the correction factor obtained using equation 2 is $2.74 \mathrm{kPa} /{ }^{\circ} \mathrm{C}\left(0.22 \mathrm{psi} /{ }^{\circ} \mathrm{F}\right)$. Corrected stresses using this equation are close in value to the stresses corrected with the polynomial equations. Significant load increases after day 90 were caused by redistribution of overburden load. At this time, the longwall shearer was approximately $76 \mathrm{~m}(250 \mathrm{ft})$ from earth pressure cells 2 and 3 and approximately $106 \mathrm{~m}(348 \mathrm{ft})$ from earth pressure cells 4 and 5 .

\section{LUCKY FRIDAY MINE}

Hecla Mining Co., Coeur d'Alene, ID, operates the Lucky Friday Mine in Mullan, ID, using a mechanized underhand cut-and-fill method to mine lead-silver ore from a steeply dipping, 2.4-m- (8-ft) wide vein at a depth exceeding $1.6 \mathrm{~km}$ (1 mile) (Scott, 1990). A series of mining cuts approximately 3.3 $\mathrm{m}(11 \mathrm{ft})$ high and 2 to $3 \mathrm{~m}(6$ to $10 \mathrm{ft})$ wide are excavated about $75 \mathrm{~m}(250 \mathrm{ft})$ along the vein on each side of an access ramp. The broken ore is stored in a muck bay on the opposite side of the vein from the access ramp. After each cut, 2- or 2.4-m- (6.6- or 8-ft) long Dywidag rock bolts are driven vertically on 1.2-m (4-ft) centers into loose muck on the floor and stabilized with wire tied to mesh on the stope walls. A four-way truss is installed at the center of the intersection using No. 7 Dywidag rock bolts that have a minimum yield strength of $160 \mathrm{kN}(36,000 \mathrm{lb})$. The truss consists of one vertical rock bolt, four legs angled $15^{\circ}$ to $20^{\circ}$ from the horizontal, one four-way horn bracket, and four stirrup U-bolts bent upward at $25^{\circ}$ from the horizontal. The near-horizontal legs consist of two or three rock bolts coupled together with their ends extending into the east and west sides of the stope along the vein and into the slot and muck bay (figure 4). After reinforcing members are installed in the intersection, backfill consisting of mill tailings, water, and $10 \%$ cement by weight is delivered from the surface to the stope. Approximately $70 \%$ of the stope height is backfilled, leaving a 1-m (3-ft) gap between fill sills. After the cut beneath the backfilled stope is mined, chain link fencing, a bearing plate, and a nut are secured to the bottom end of each exposed rock bolt for ground support (Williams et al., 2001 ). 
To monitor stability and provide data for rock mechanics analysis during subsequent mining of the backfilled stope at the intersection of the 5660-05 level, instruments (string potentiometers, instrumented rock bolts, rock bolt load cells, and earth pressure cells) were installed in the stope. Eight of Geokon's model 3500 earth pressure cells were installed in the cemented backfill, two of which were equipped with thermistors to monitor temperature (Geokon, 2004). They were secured with bailing wire to wire mesh near the stope walls or to Dywidag rock bolts near the intersection. The range for these instruments was chosen on the basis of previous research at the mine. Earth pressure cell 1A was installed near the stope wall, and earth pressure cell I was placed near the center of the intersection formed by the vein, muck bay, and access ramp (figure 4). This placement enabled the horizontal stress gradient across the stope to be monitored.

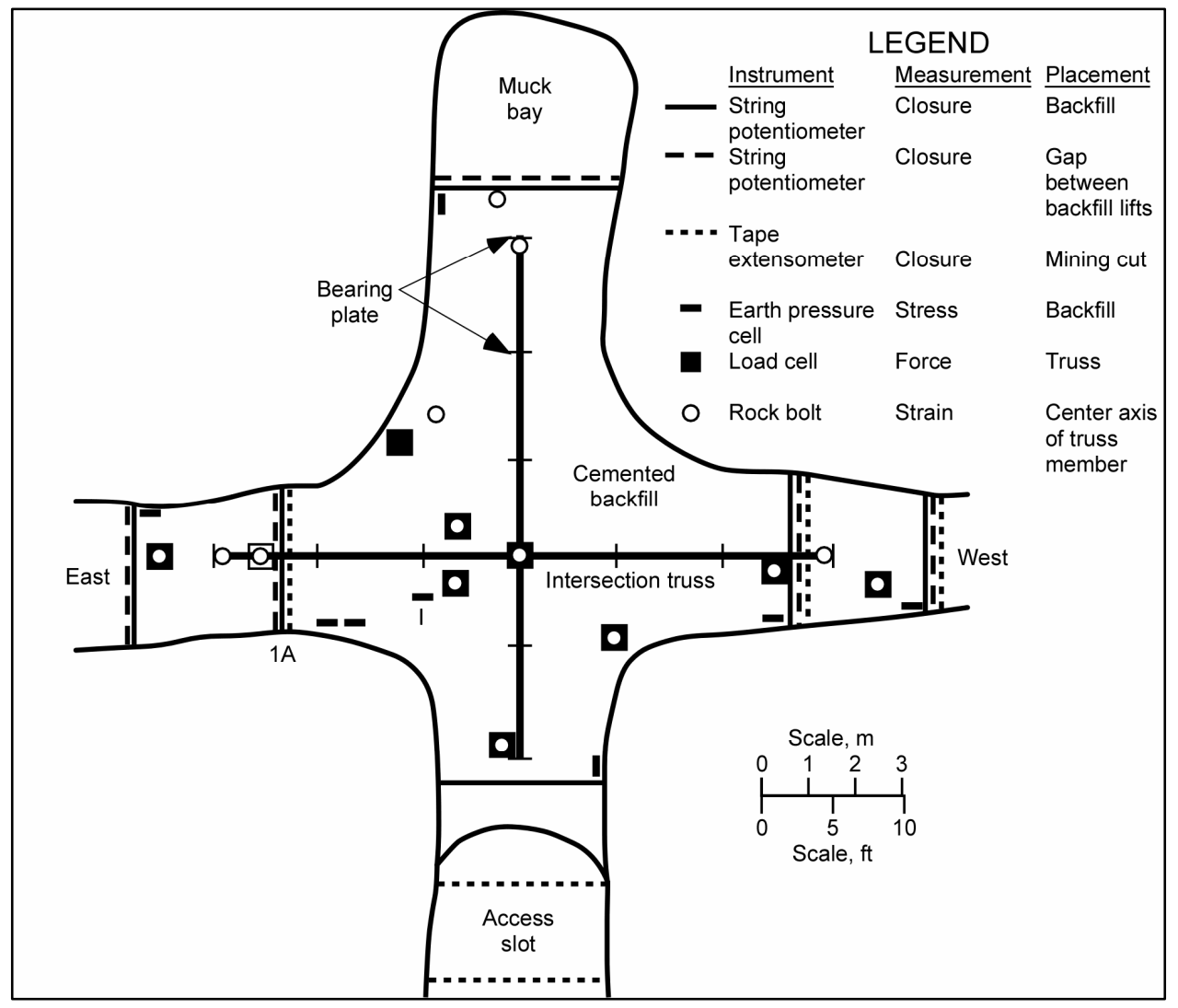

Second-order polynomials fit to stress-versus-temperature plots recorded during the first 36 hours after the stope was backfilled were used to correct stress readings for temperature-induced stress changes (figure A25). The approximate stress applied to the face of the earth pressure cells by the weight of the backfill placed mid-height in the stope was $7 \mathrm{kPa}(1 \mathrm{psi})$ (equation 5). At $46^{\circ} \mathrm{C}(115$ ${ }^{\circ} \mathrm{F}$ ), the temperature-induced stress for earth pressure cell $\mathrm{I}$ is $207 \mathrm{kPa}$ (30 psi), illustrating the importance of correcting stress readings with temperature data.

Figure 4.-Plan view of 5660-05-level intersection with instrument locations at the Lucky Friday Mine.

$$
\sigma \quad=[v /(1-v)] \times(\gamma \times h),
$$

where $\quad \sigma=$ stress from weight of backfill, $\mathrm{kPa}(\mathrm{psi})$,

$v \quad=$ Poisson's ratio $=0.25$,

$\gamma=$ specific weight of backfill, $2,002 \mathrm{~kg} / \mathrm{m}^{3}\left(125 \mathrm{lb} / \mathrm{ft}^{3}\right)$,

and $\quad \mathrm{h} \quad=$ height of backfill above earth pressure, $\mathrm{m}(\mathrm{ft})$.

Theoretical correction factors were also calculated using average backfill deformation moduli obtained from 7- and 28-day laboratory tests equal to 1,041 and 1,370 MPa (151,000 and 198,700 psi), respectively (Williams et al., 2001). Using equation 2, the 7-day and 28-day moduli yield 4.86 and $6.39 \mathrm{kPa} /{ }^{\circ} \mathrm{C}\left(0.39\right.$ and $\left.0.52 \mathrm{psi} /{ }^{\circ} \mathrm{F}\right)$, respectively. The smaller value was used to correct stress readings from days 1 through 14, while the larger value was used to correct the remaining stresses. The maximum 
difference between stresses corrected by the polynomial equation and by equation 2 was $70 \mathrm{kPa}(10 \mathrm{psi})$ for earth pressure cell I and only $28 \mathrm{kPa}$ (4 psi) for earth pressure cell 1A (figures A26 and A27). The abrupt stress increase starting approximately at day 10 was caused by undercutting the backfilled stope.

\section{EQUATIONS FOR COMBINED DATA}

Two functions were fit to temperature-versus-stress data collected from all earth pressure cells with little or no applied load. Data with temperatures between $16^{\circ} \mathrm{C}$ and $35^{\circ} \mathrm{C}\left(61^{\circ} \mathrm{F}\right.$ and $\left.95^{\circ} \mathrm{F}\right)$ were fit to a second-order polynomial, and data with temperatures greater than $35^{\circ} \mathrm{C}\left(95^{\circ} \mathrm{F}\right)$ were fit to an exponential function. Two equations, as opposed to just one, were used to increase the square of the correlation coefficient. Accounting for the effects of temperatures may not be critical if the backfill has a sufficiently large safety factor; however, for applications such as the backfill span study at the Turquoise Ridge Mine, where a complete understanding of stress transfer mechanisms requires knowledge of small amounts of loading on the backfill, it is important to account for temperatureinduced stresses.

\section{CONCLUSIONS}

The total stress change attributable to mining alone in four backfilled stopes at the Turquoise Ridge Mine was calculated by summing individual, observable stress changes during periods of active mining. These benchmark values were compared to the last stress measurements recorded during this study by each earth pressure cell to evaluate the accuracy of three methods used to correct for the effects of temperature. In one method, polynomial equations were fit to temperature-induced stress-versustemperature readings for earth pressure cells undergoing little or no load. In another method, a theoretically derived correction factor was based on the properties of earth pressure cells and backfill. In the third method, an average correction factor was obtained from the slope of the line formed from stress-versus-temperature data collected during periods of no mining. The final corrected stress recorded in each backfilled stope was closer to the benchmark values obtained using the last method. The theoretically derived correction factor for the backfill at the Turquoise Ridge Mine is $10.6 \mathrm{kPa} /{ }^{\circ} \mathrm{C}(0.86$ $\left.\mathrm{psi} /{ }^{\circ} \mathrm{F}\right)$. Correction factors calculated from field data during nonmining periods ranged from 7.7 to 31.5 $\mathrm{kPa} /{ }^{\circ} \mathrm{C}\left(0.62\right.$ to $\left.2.54 \mathrm{psi} /{ }^{\circ} \mathrm{F}\right)$.

1. Applying the theoretical values and the polynomial equation to stresses recorded at the Foidel Creek and Lucky Friday mines resulted in similar, and, in some cases, identical, values.

2. Using reinitialized stresses after initial temperature spikes and summing individual stress changes caused by mining helped in interpreting seemingly meaningless data.

3. Large temperature changes can greatly affect the stress magnitude in an earth pressure cell. For lowstrength backfill mixes, this apparent stress could be a significant percentage of the backfill's unconfined compressive strength.

4. Temperature changes can cause negative stress.

5. The effect of temperature on stress magnitude in an earth pressure cells can be identified by plotting stress versus elapsed time and temperature versus elapsed time on the same graph.

6. Temperature-induced stress readings do not always follow the same path during heating and cooling cycles, which implies a hysteresis effect. 
7. Using the correction factor provided by the manufacturer accounts for a small percentage of the temperature effects on the instrument because this correction factor compensates only for the transducer and not the entire instrument body.

8. The effects of temperature on stress are nearly eliminated for most nonmining intervals by applying the average correction factor obtained from the slope of the line of vertical stress versus temperature for these periods.

9. None of the methods used completely eliminated the effect of temperature on stress readings.

10. Laboratory tests to determine the effects of temperature on stress at various stress levels would be a valuable topic for future research.

\section{ACKNOULEDGMENTS}

The authors wish to express their appreciation to the following people for assistance with instrument installation and logistic support: Rob Usher, Brian Simmons, Bob Schuler, Bert Bellows, Chris Jacobsen, John Evans, and Rick Smith, of the Turquoise Ridge Mine, Placer Dome, Inc., Golcanda, NV; Gary Buchan, Rocky Thompson, and Joe Shoemaker, of the Foidel Creek Mine, Cyprus Twentymile Coal Co., Oak Creek, CO; Bill Lane, Tom Yanske, and Greg Sutton, The Doe Run Company, MO; and Clyde Peppin and Doug Bayer of the Lucky Friday Mine, Hecla Mining Co., Mullan, ID. The authors also gratefully acknowledge the following NIOSH-SRL personnel for assistance in installing the instruments: Rich Rains, John Dunford, Bob McKibbin, Paul Pierce, Eric Zahl, and Dave Denton. The timely delivery of instruments by Tony Simmonds, Brian Brown, and Mike McDonough, Geokon, Inc., to meet changing mine schedules is greatly appreciated.

Suggestions from Rimas Pakalnis, University of British Columbia, Vancouver, BC, Guner Gurtunca, Pittsburgh Research Laboratory, Pittsburgh, PA; and Barrie Sellers, Geokon, Inc., significantly enhanced this work.

\section{REFERENCES}

Berentsen, E.J, R.F. Nanna, J.S. Hazlitt, and L.D. Estes. Discovery and Geology of the Turquoise Ridge Gold Deposit. Mining Engineering, Oct. 1996, pp. 31-35.

Carter, R. Cyprus Amax Coal Co.’s Western Operations. Coal Age, Dec., 1996, 26 pp.

Daigle, L., and J.Q. Zhao. Assessing Temperature Effects on Earth Pressure Cells. National Research Council Canada, Research Report 131, Feb. 2003, 31 pp.

Dunicliff, J., and G.E. Green. Geotechnical Instrumentation for Monitoring Field Performance. Wiley, 1998, 577 pp.

Geokon, Inc. Instruction Manual, Models 4800/4810/4820, Vibrating Wire Earth Pressure Cells. 1996, 23 pp.

Geokon, Inc. www.geokon.com/products/datasheets/4800.pdf. November 2004. 
Sellers, B. Temperature Effects on Earth Pressure and Concrete Stress Cells: Some Theoretical Considerations. Geotechnical Instrumentation News, vol. 18, no. 1, 2000, pp. 23-24.

Seymour, B., D. Tesarik, M.K. Larson, and J. Shoemaker. Stability of Backfilled Cross-Panel Entries During Longwall Mining. Paper in Proceedings of 17th International Conference on Ground Control in Mining, ed. by Syd S. Peng (Univ. of WV, Morgantown, WV, Aug. 4-6, 1998). 1998, pp. 11-20.

Scott, D. F. Relationship of Geologic Features to Rock Bursts, Lucky Friday Mine, Mullan, Idaho. Paper in Rockbursts and Seismicity in Mines. Proceedings of the 2nd International Symposium on Rock Bursts and Seismicity in Mines, ed. by C. Fairhurst (Minneapolis, MN, June 8-10, 1988). Balkema, 1990, pp. 401-406.

Tesarik, D. R., J. B. Seymour, and J. D. Vickery. Instrumentation and Modeling of the Cannon Mine's B-North Ore Body. Paper in Innovations in Mining Backfill Technology. Proceedings of 4th International Symposium on Mining With Backfill, ed. by F P. Hassani, M.J. Scoble, and T.R. Yu (Canadian Institute of Mining and Metallurgy, Montreal, PQ, Oct. 2-5, 1989). Balkema, 1989, pp. 129138.

Williams, T.J., D.K. Denton, M.K. Larson, R.L. Rains, J.B. Seymour, and D.R. Tesarik. Geomechanics of Reinforced Cemented Backfill in a Underhand Stope at the Lucky Friday Mine, Mullan, Idaho. NIOSH Report of Investigations 9655, July 2001, 18 pp. 
APPENDIX 


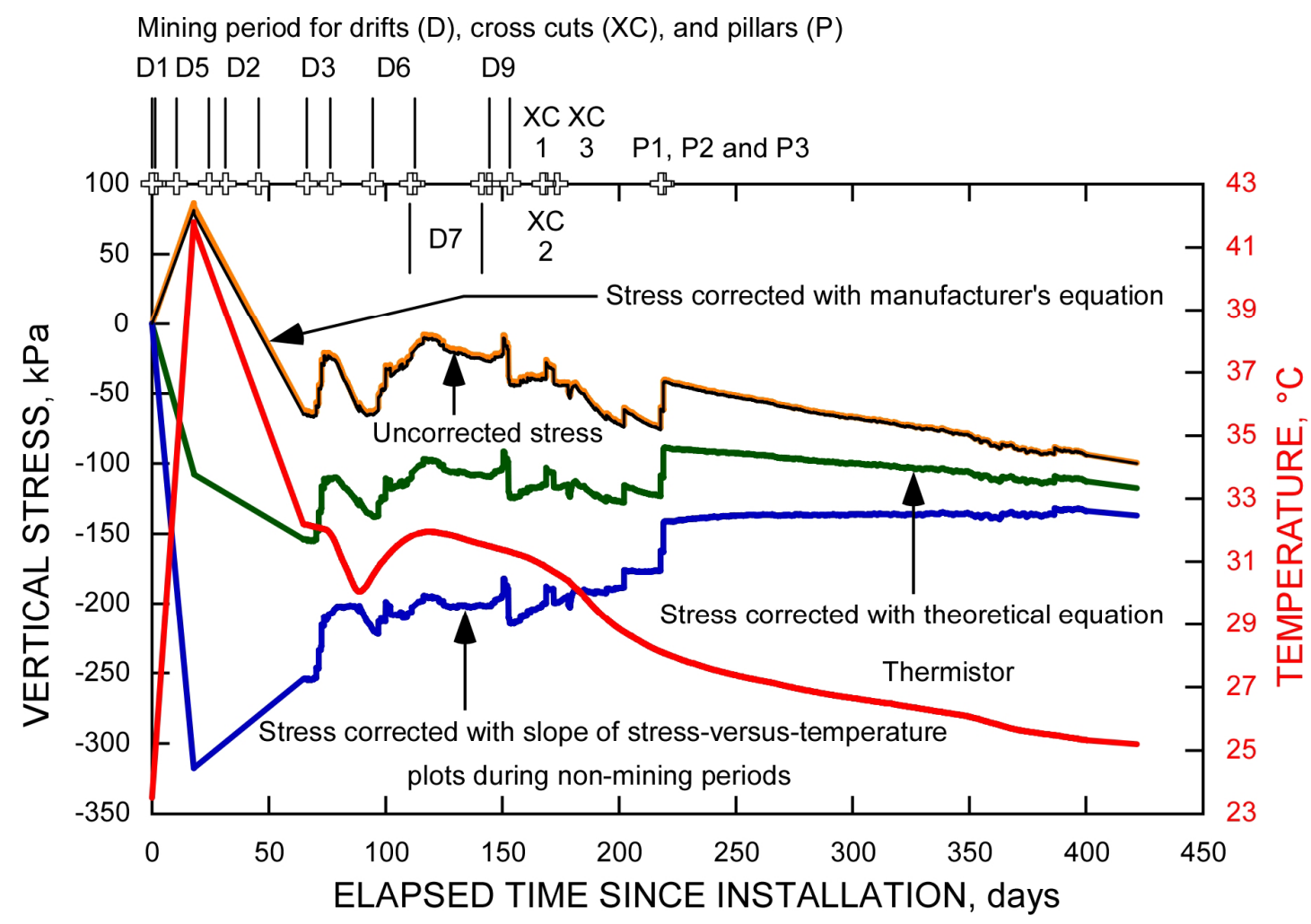

Figure A1.-Vertical stress and temperature versus elapsed time for earth pressure cell 1 at the Turquoise Ridge Mine.

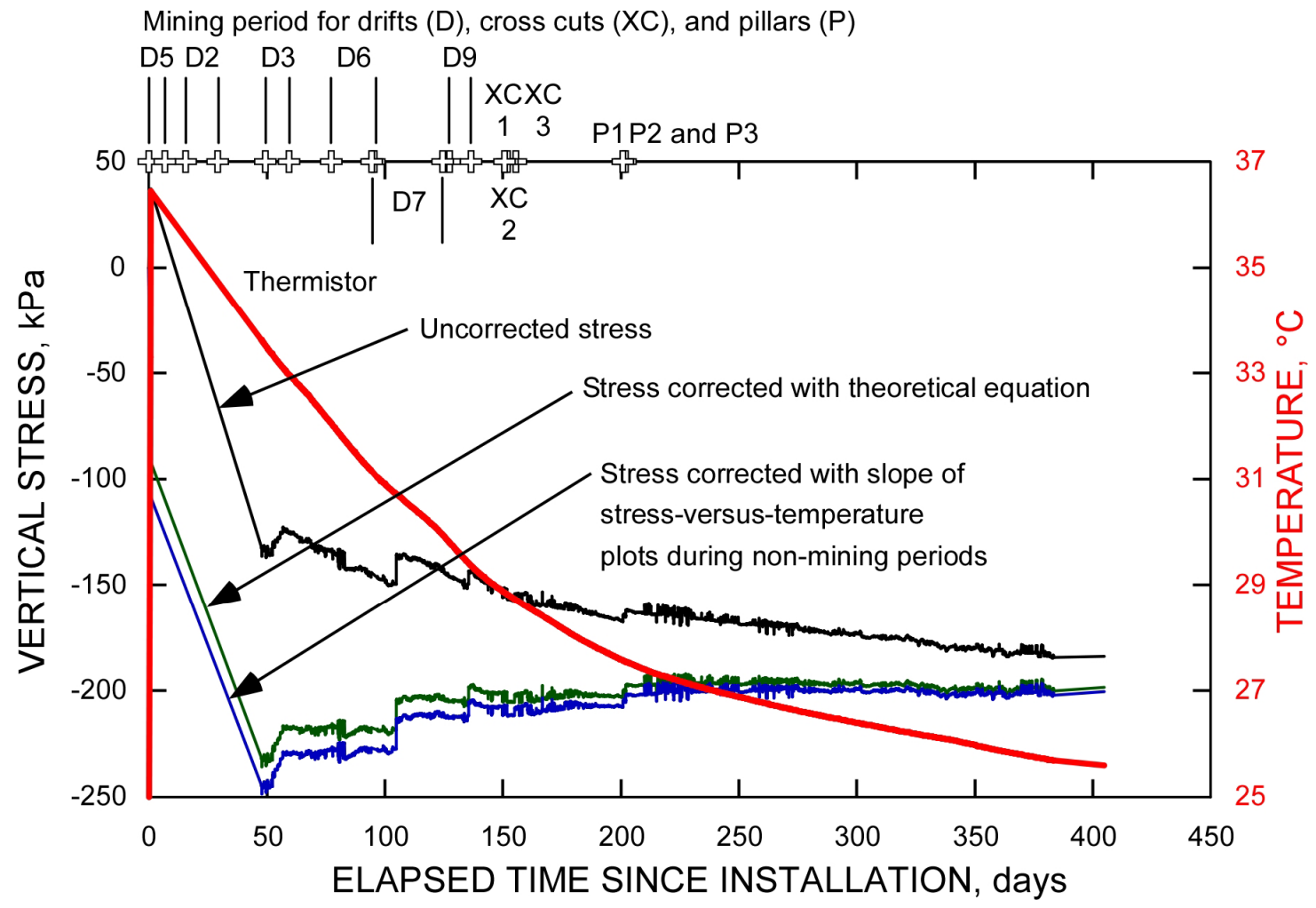

Figure A2.-Vertical stress and temperature versus elapsed time for earth pressure cell 2 at the Turquoise Ridge Mine. 


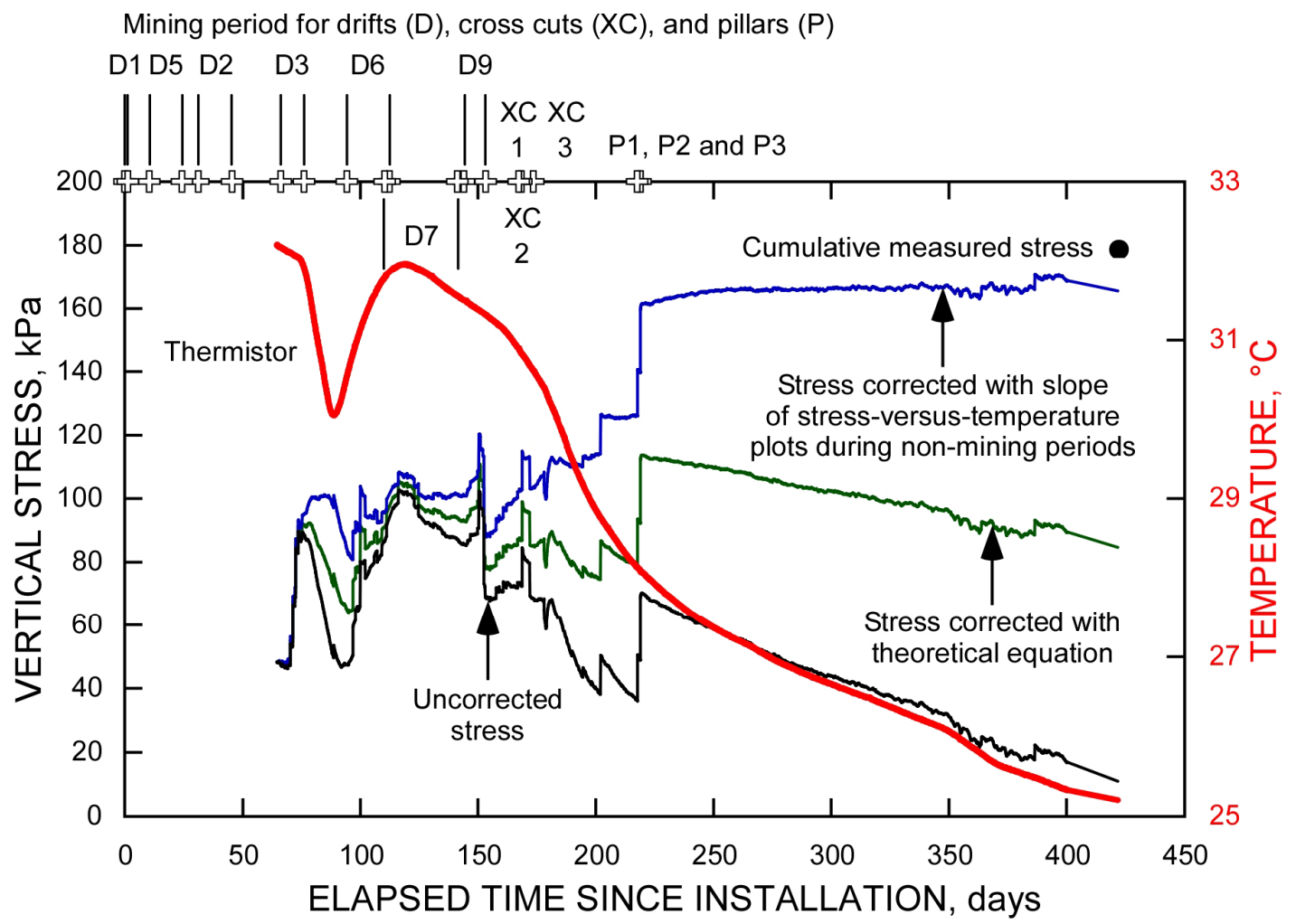

Figure A3.-Vertical stress and temperature versus elapsed time (initialized at day 65) for earth pressure cell 1 at Turquoise Ridge Mine.

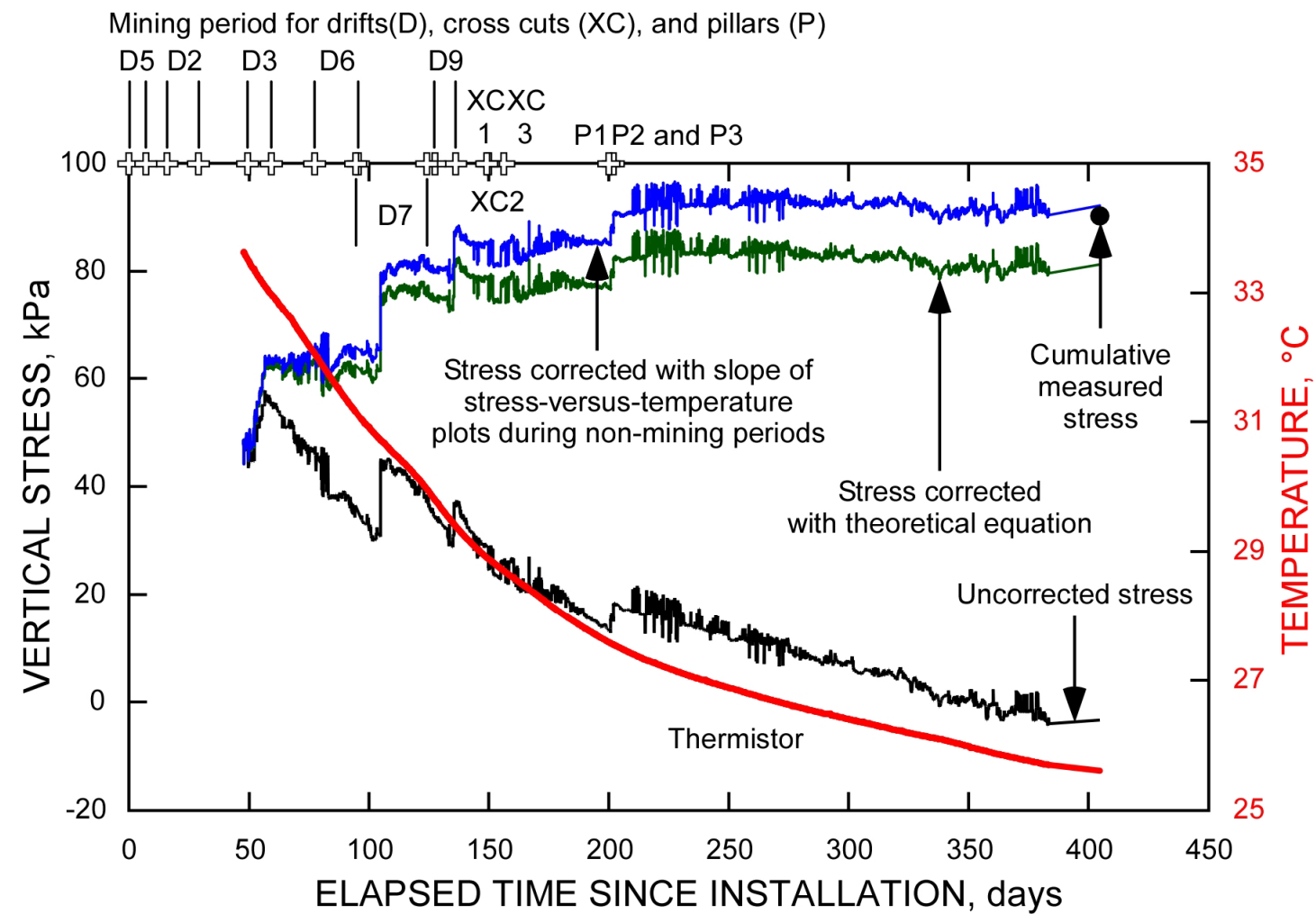

Figure A4.-Vertical stress and temperature versus elapsed time for earth pressure cell 2 (initialized at day 47) at Turquoise Ridge Mine. 
16

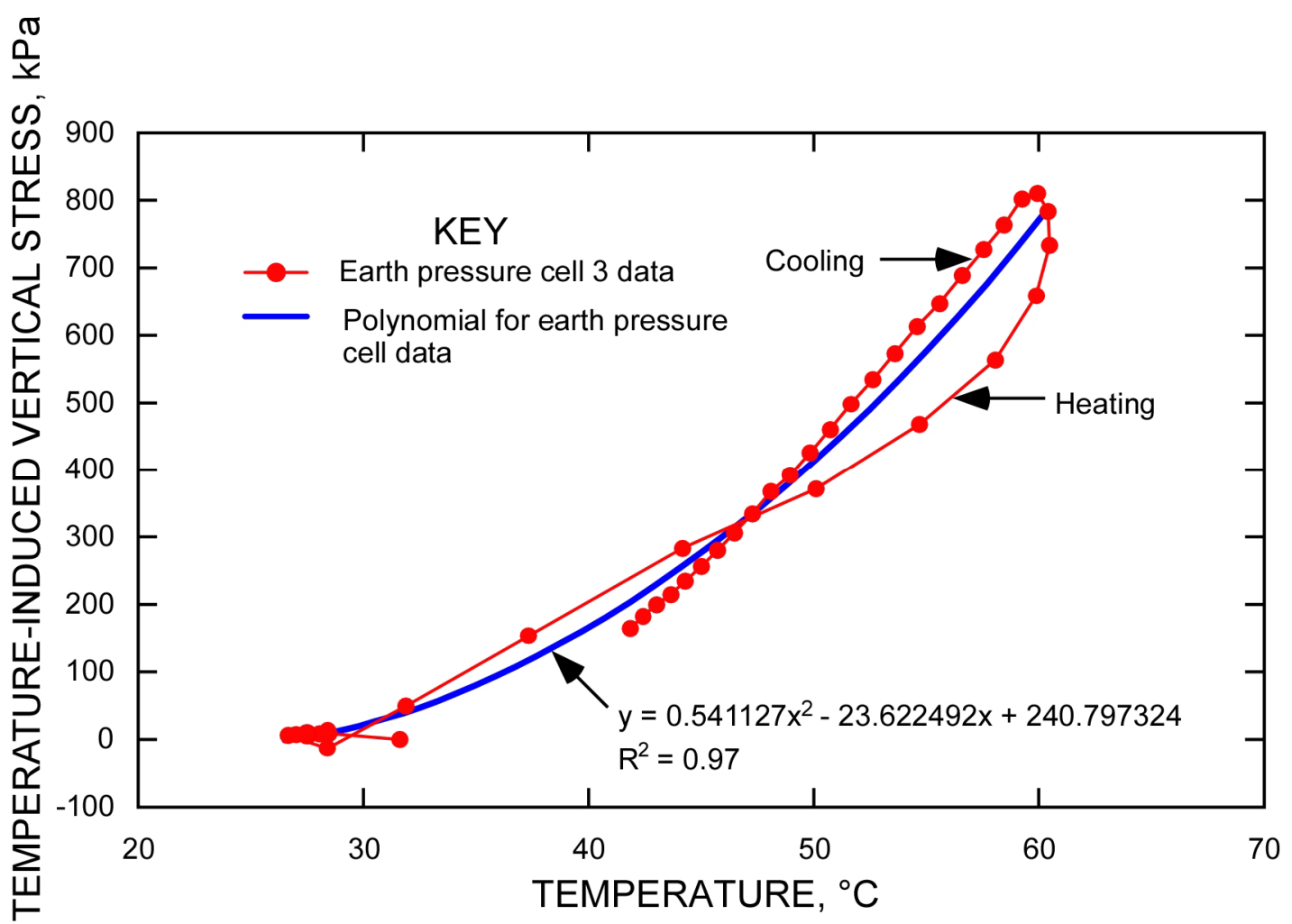

Figure A5.-Temperature-induced vertical stress versus temperature for earth pressure cell 3 at Turquoise Ridge Mine.

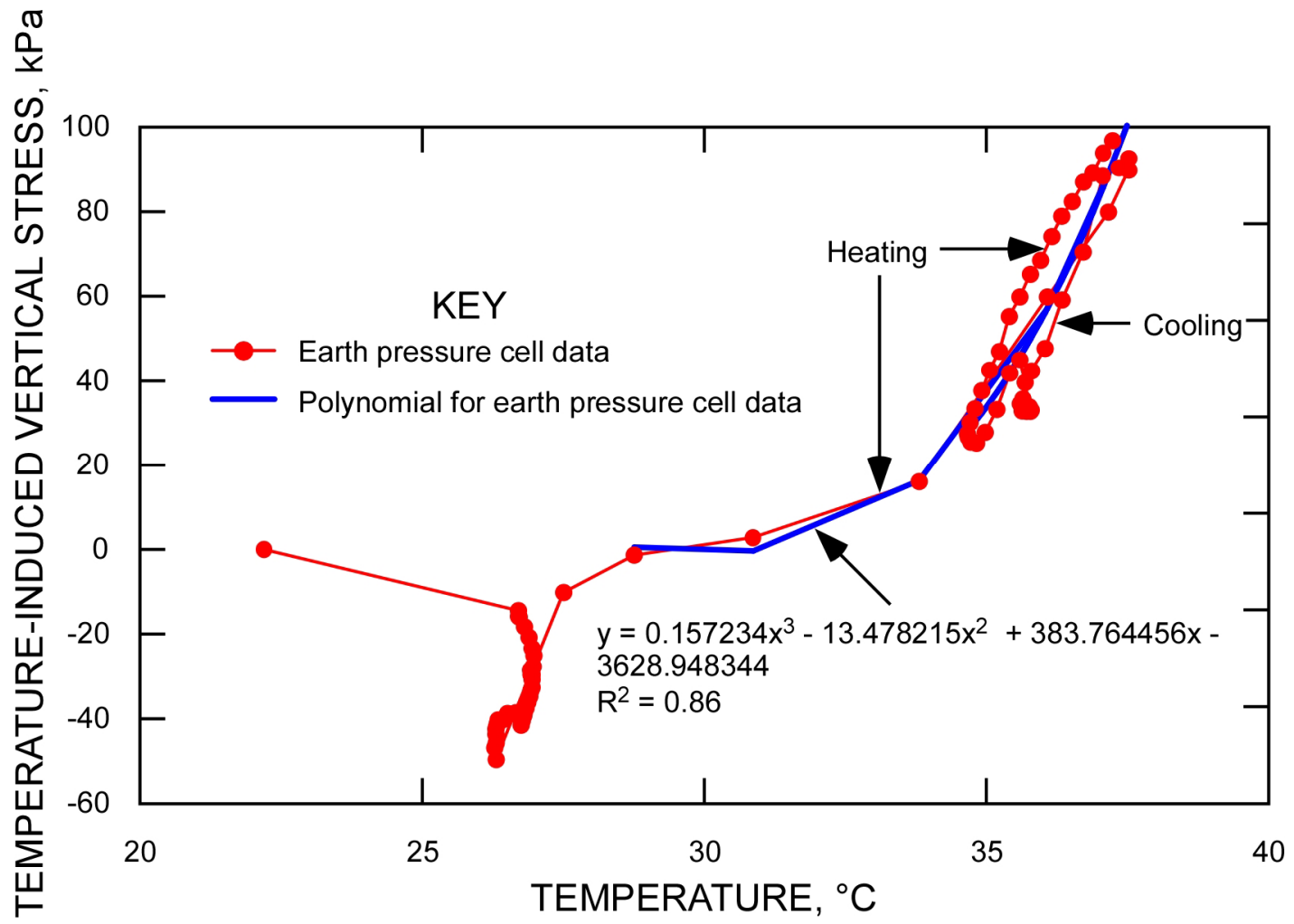

Figure A6.-Temperature-induced vertical stress versus temperature for earth pressure cell 4 at Turquoise Ridge Mine. 
Mining period for drifts $(D)$, cross cuts $(X C)$, and pillars $(P)$

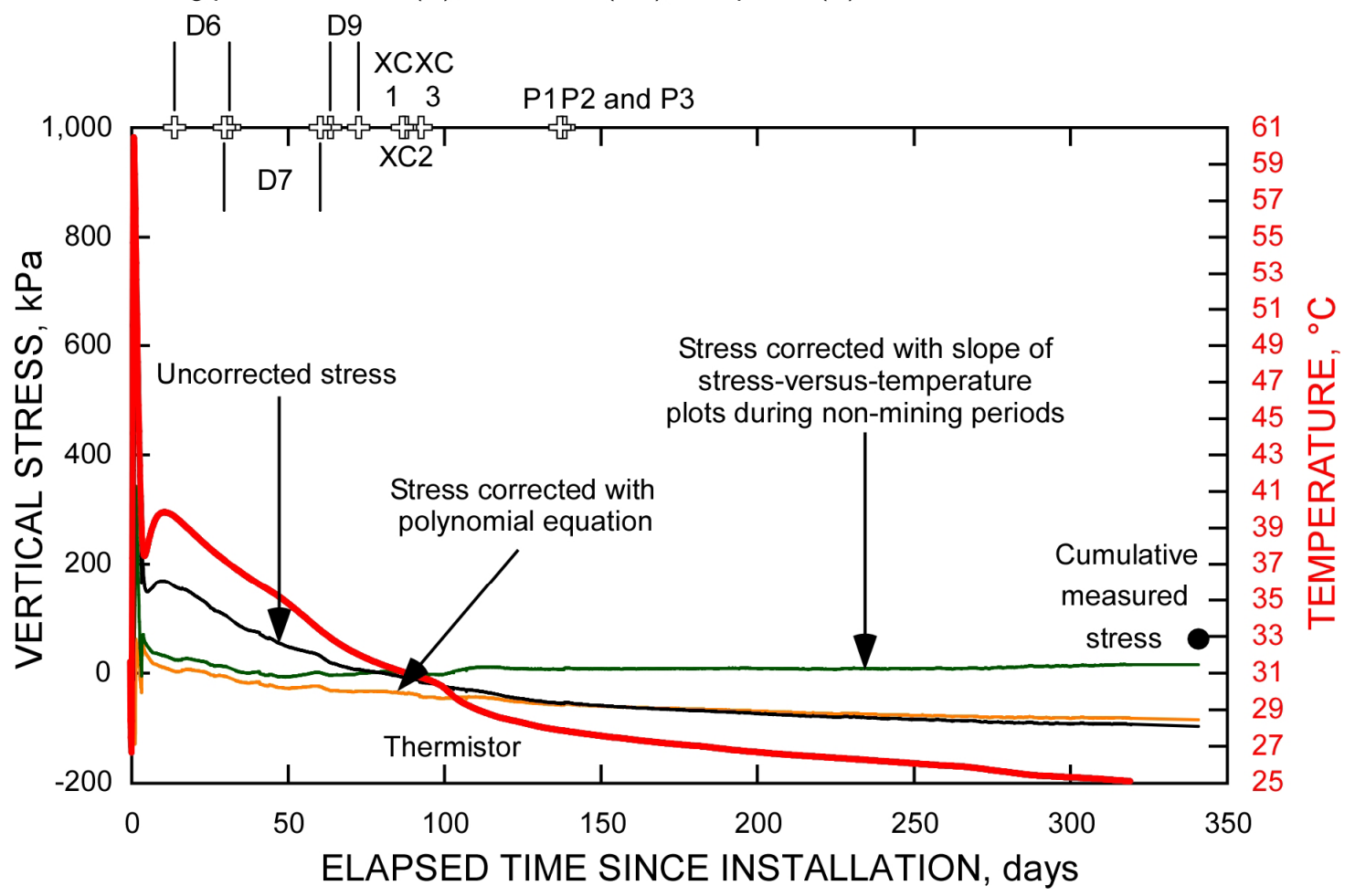

Figure A7.-Vertical stress and temperature versus elapsed time for earth pressure cell 3 at Turquoise Ridge Mine

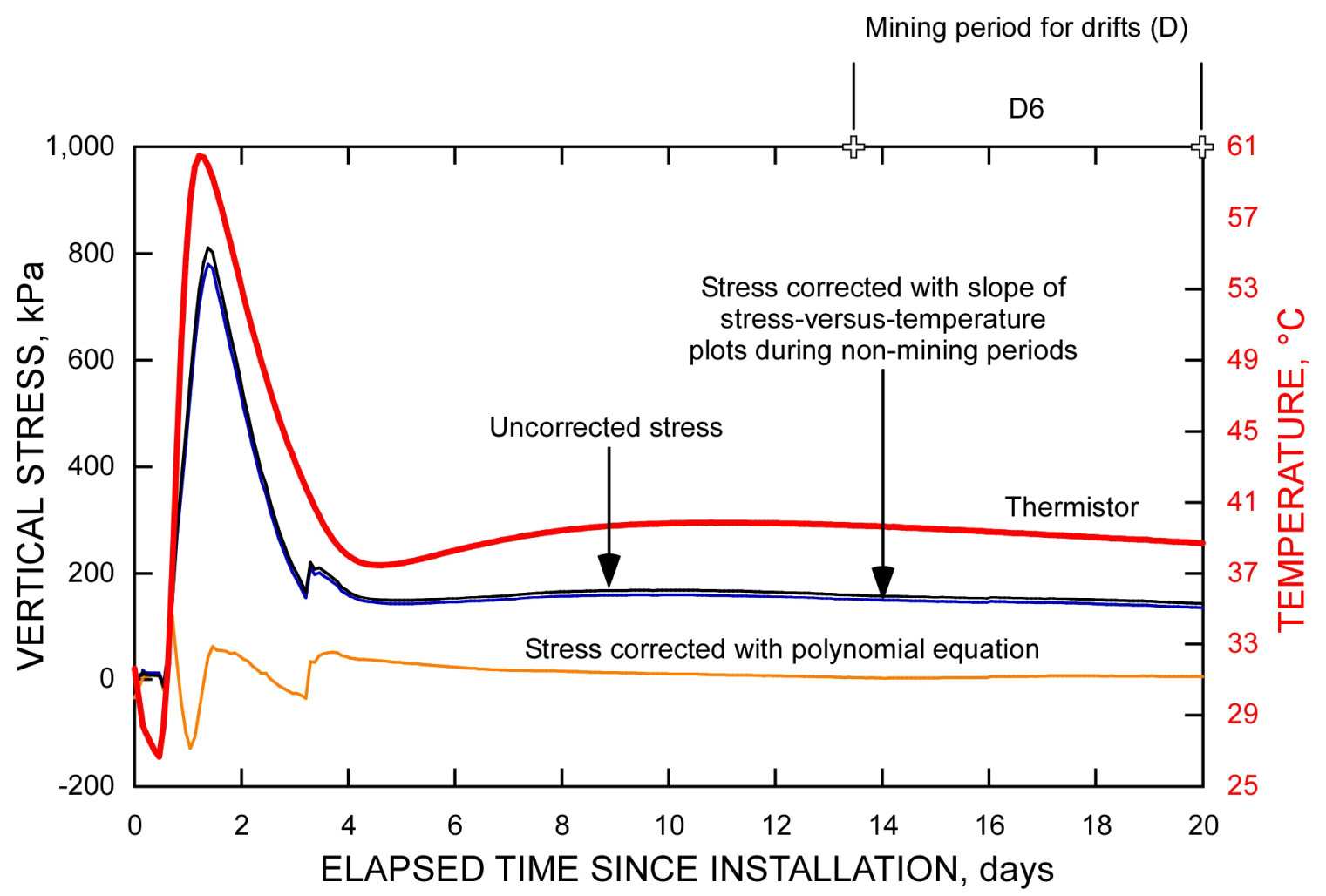

Figure A8.-Vertical stress and temperature versus elapsed time to day 20 for earth pressure cell 3 at Turquoise Ridge Mine. 


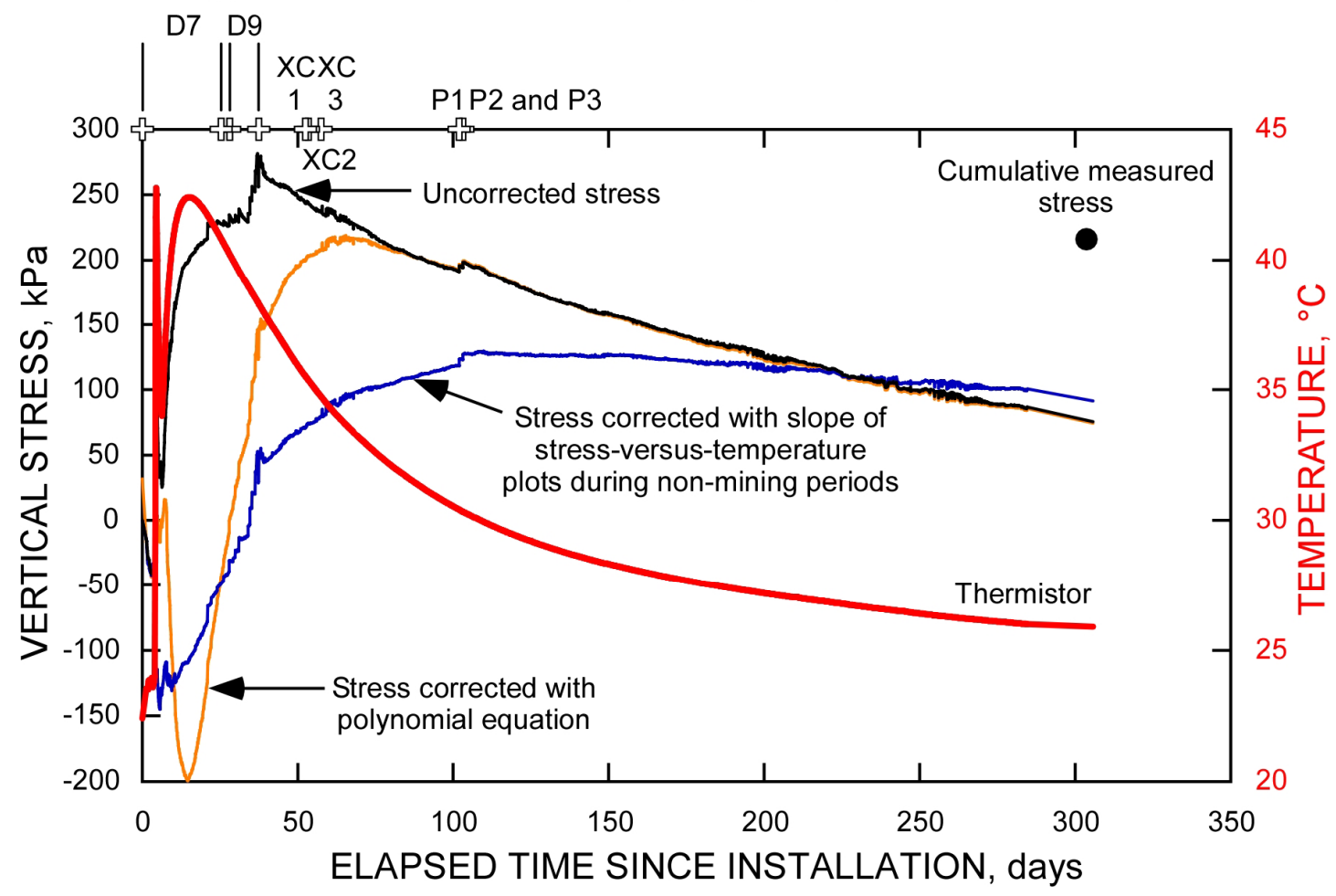

Figure A9.-Vertical stress and temperature versus elapsed time for earth pressure cell 4 at Turquoise Ridge Mine.

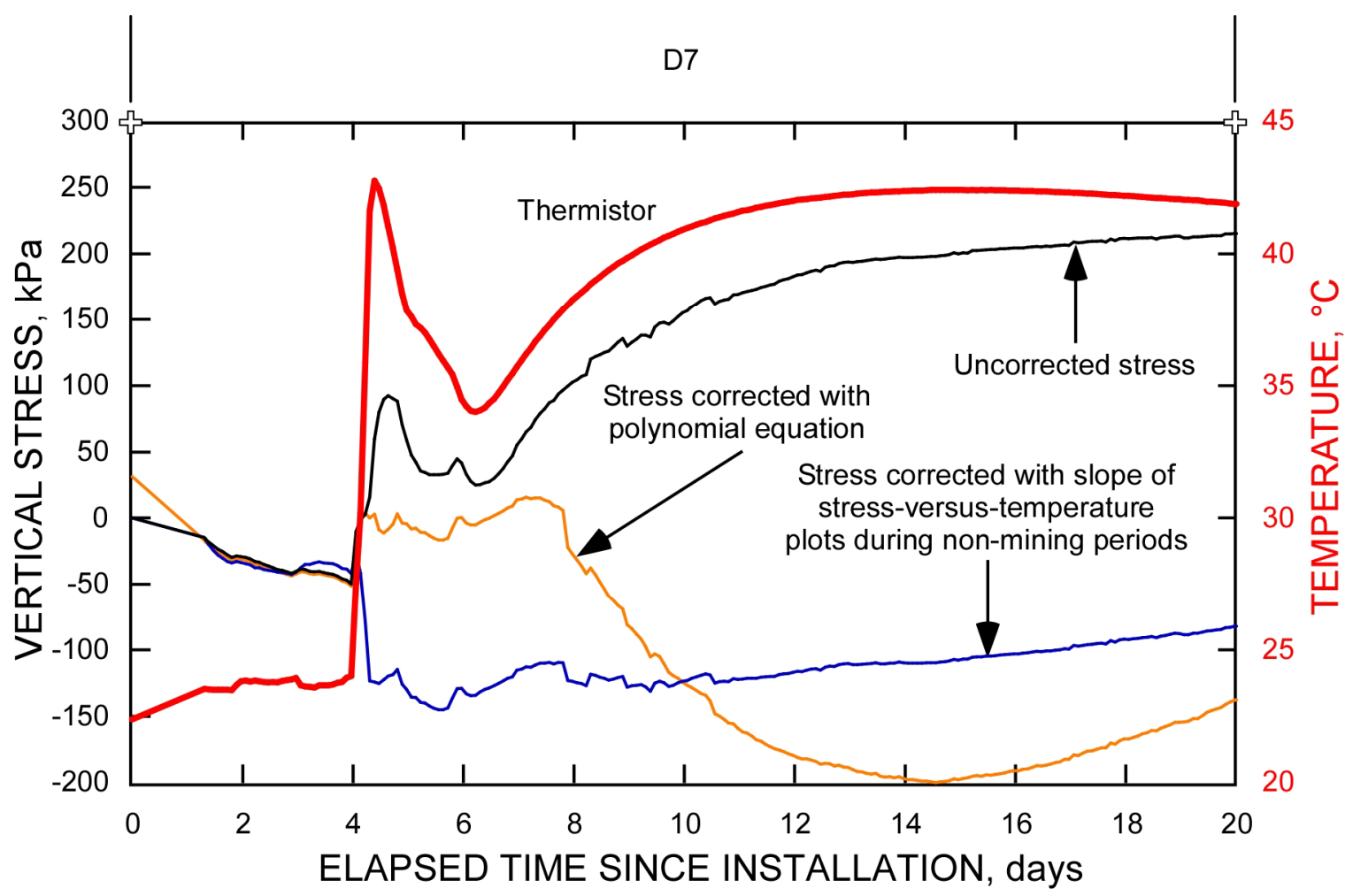

Figure A10.-Vertical stress and temperature versus elapsed time to day 20 for earth pressure cell 4 at Turquoise Ridge Mine. 


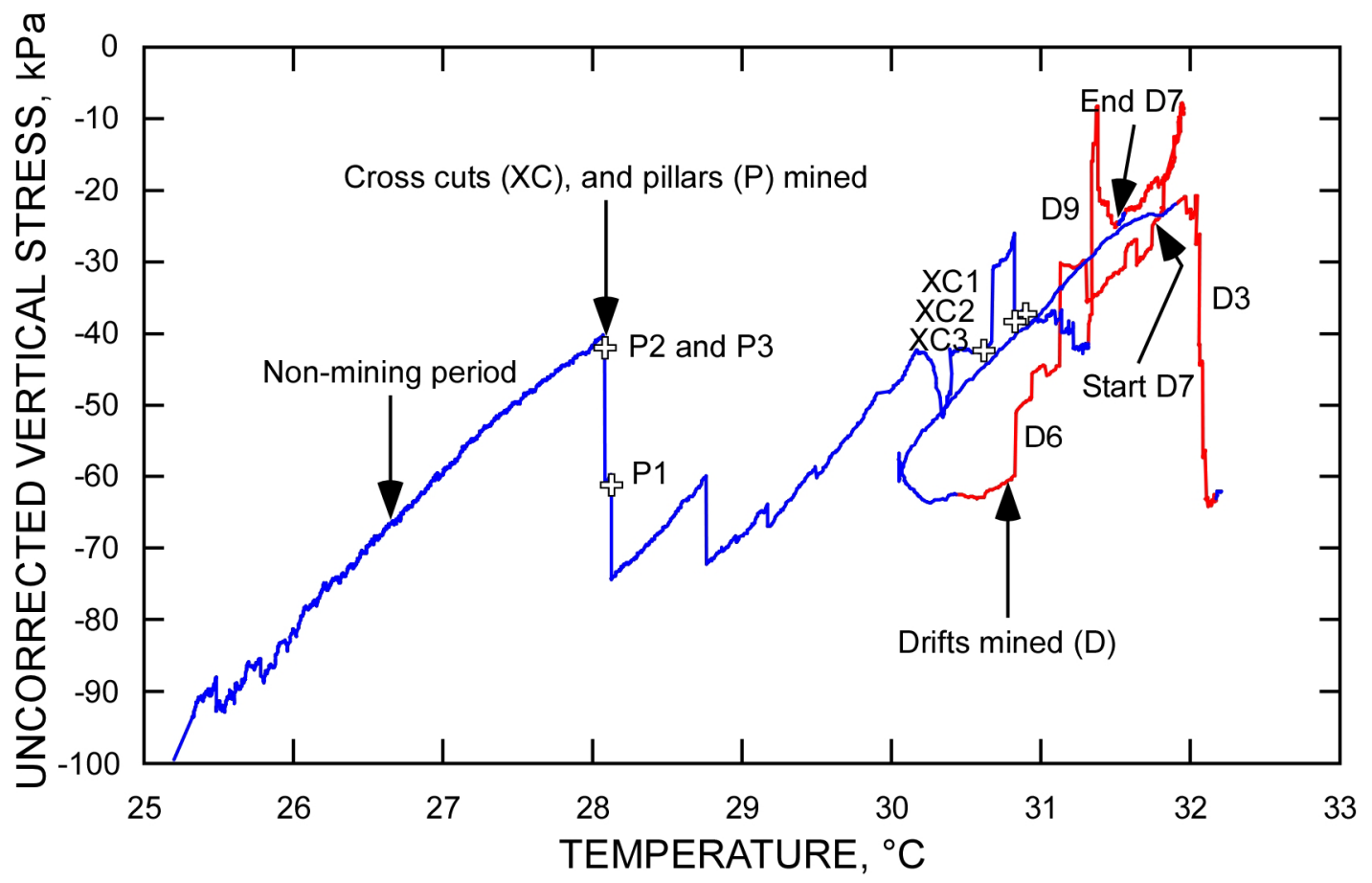

Figure A11.-Uncorrected vertical stress versus temperature for earth pressure cell 1 at Turquoise Ridge Mine.

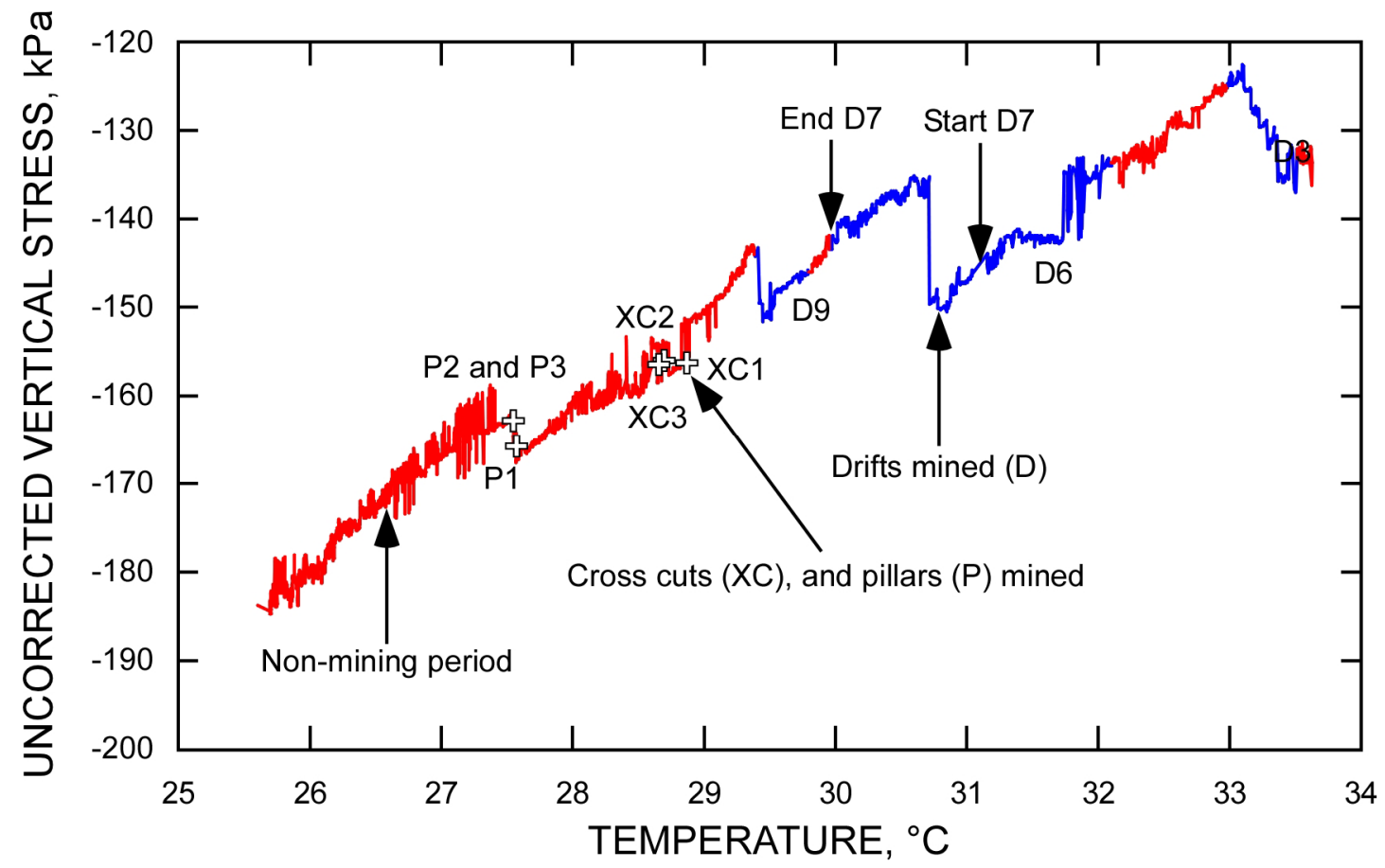

Figure A12.-Uncorrected vertical stress versus temperature for earth pressure cell 2 at Turquoise Ridge Mine. 


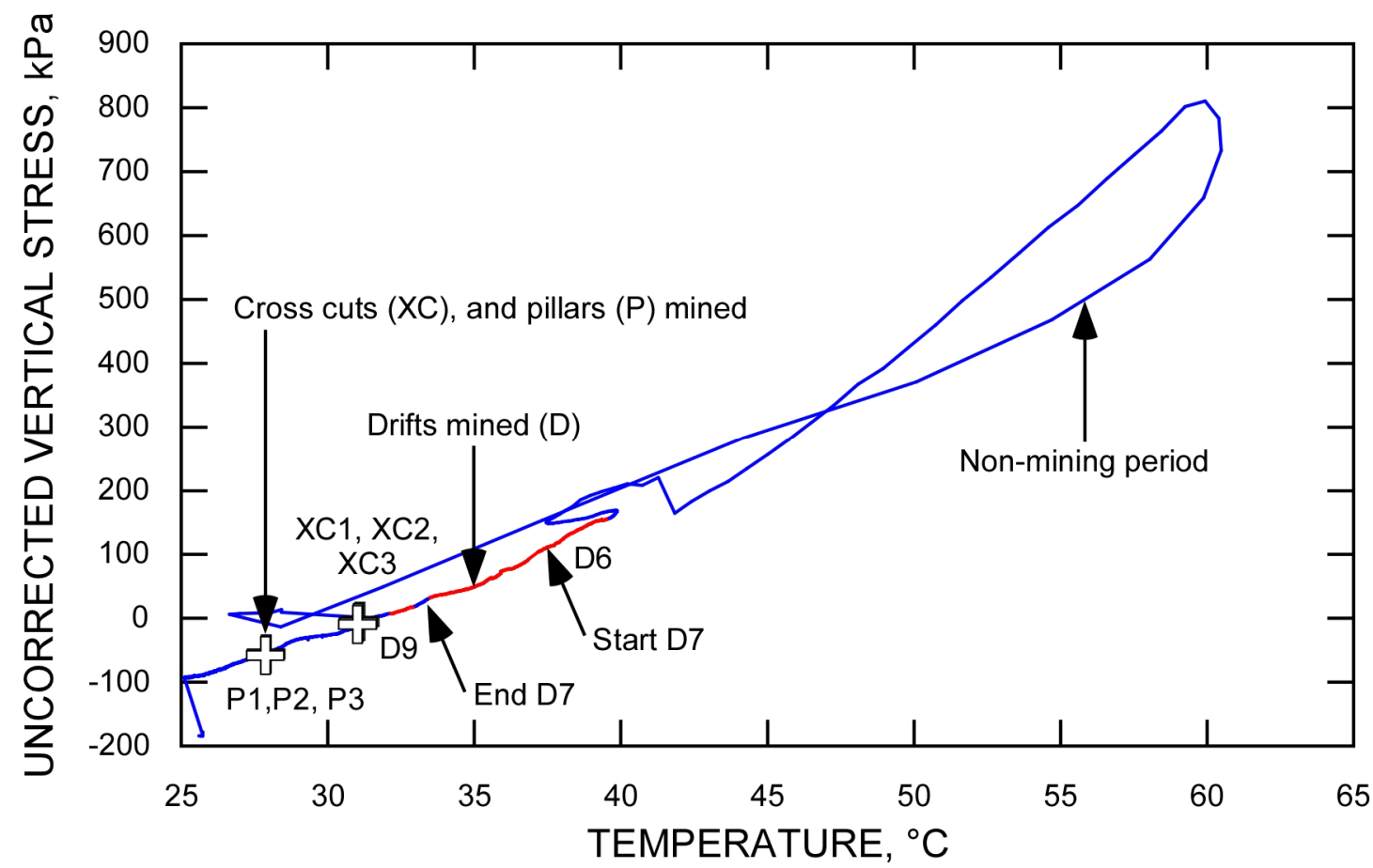

Figure A13.-Uncorrected vertical stress versus temperature for earth pressure cell 3 at Turquoise Ridge Mine.

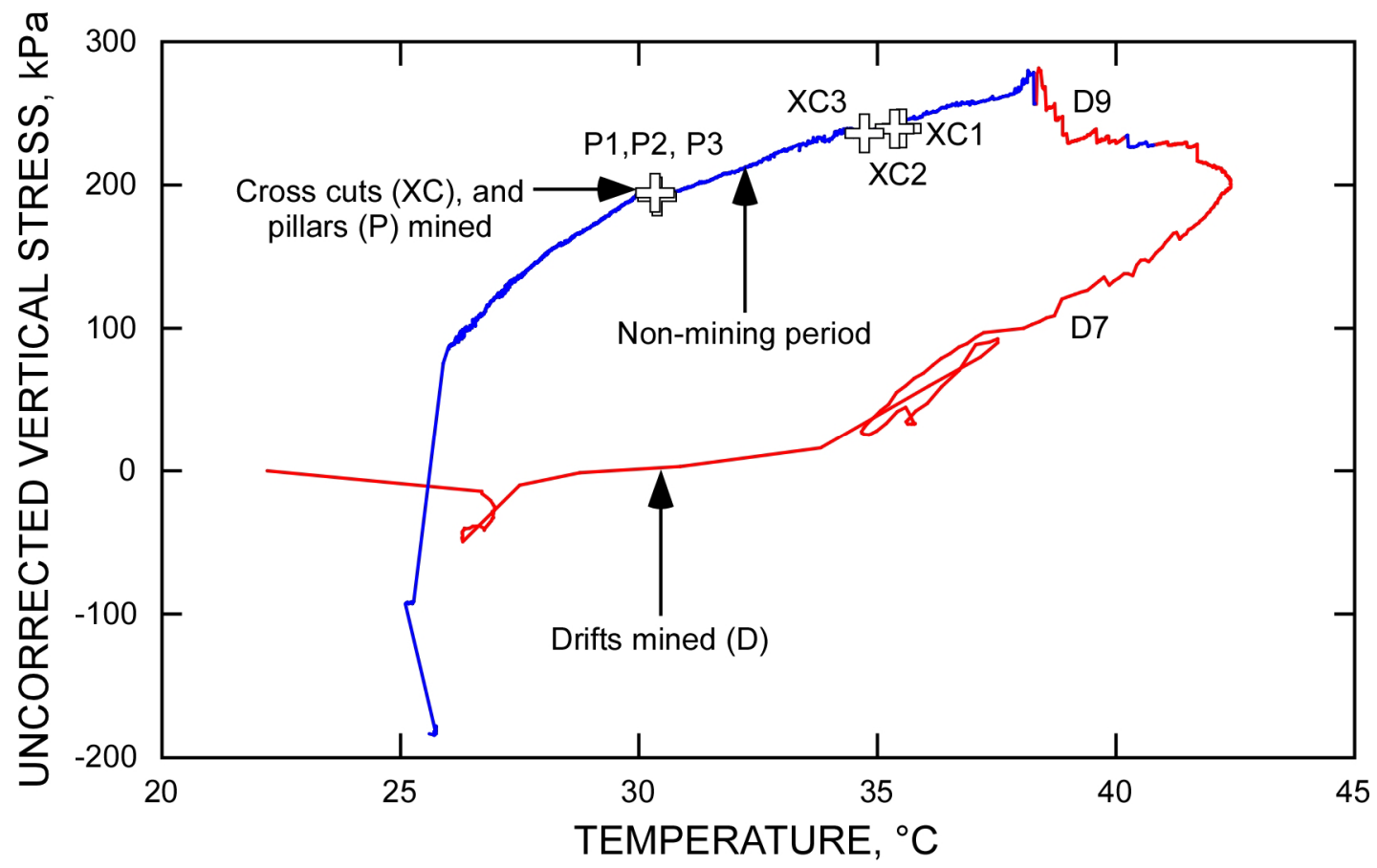

Figure A14.-Uncorrected vertical stress versus temperature for earth pressure cell 4 at Turquoise Ridge Mine. 


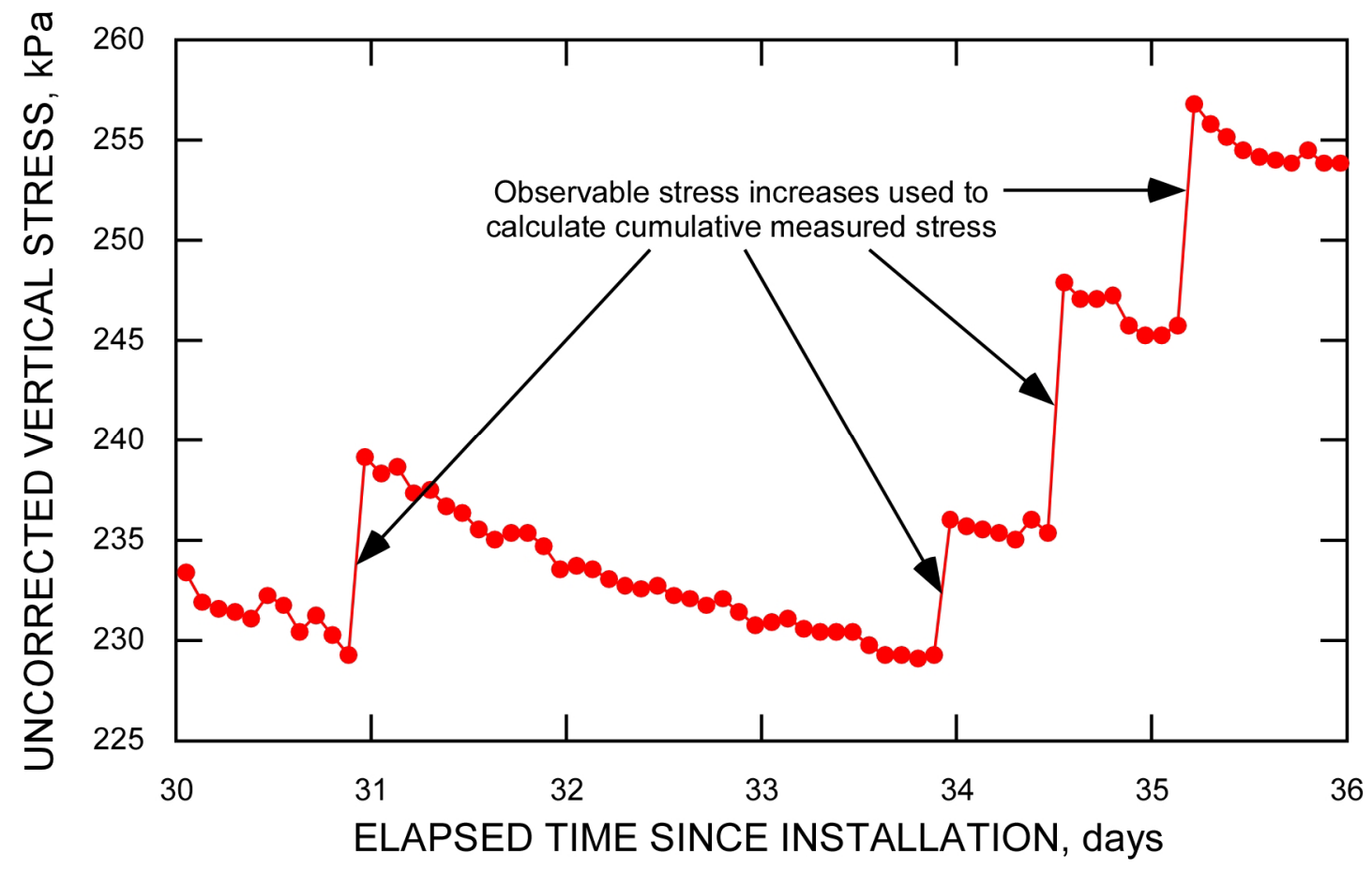

Figure A15.-Uncorrected vertical stress versus elapsed time for earth pressure cell 4 during mining of drift 9 at Turquoise Ridge Mine.

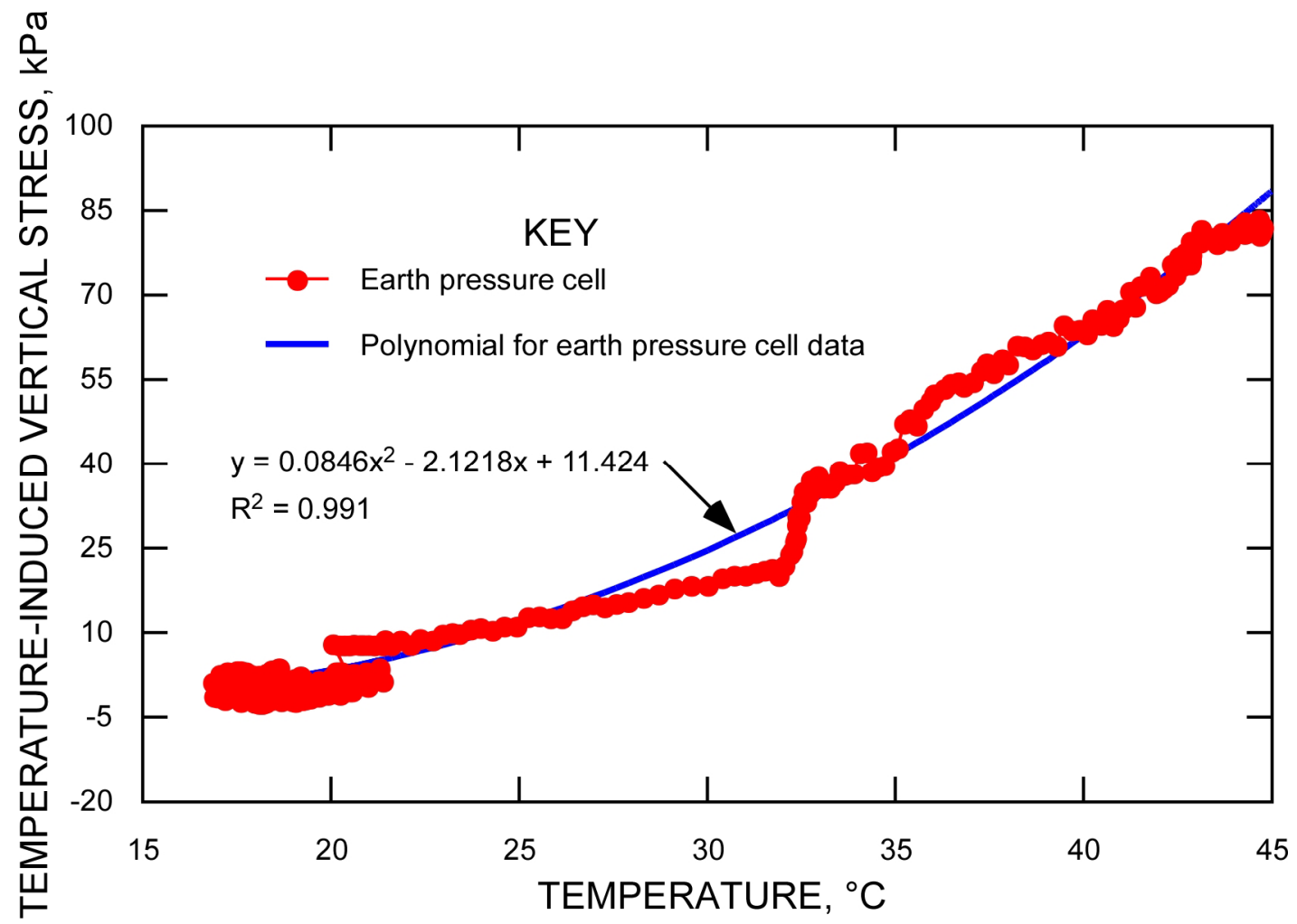

Figure A16.-Temperature-induced vertical stress versus temperature for earth pressure cell 2 at Foidel Creek Mine. 


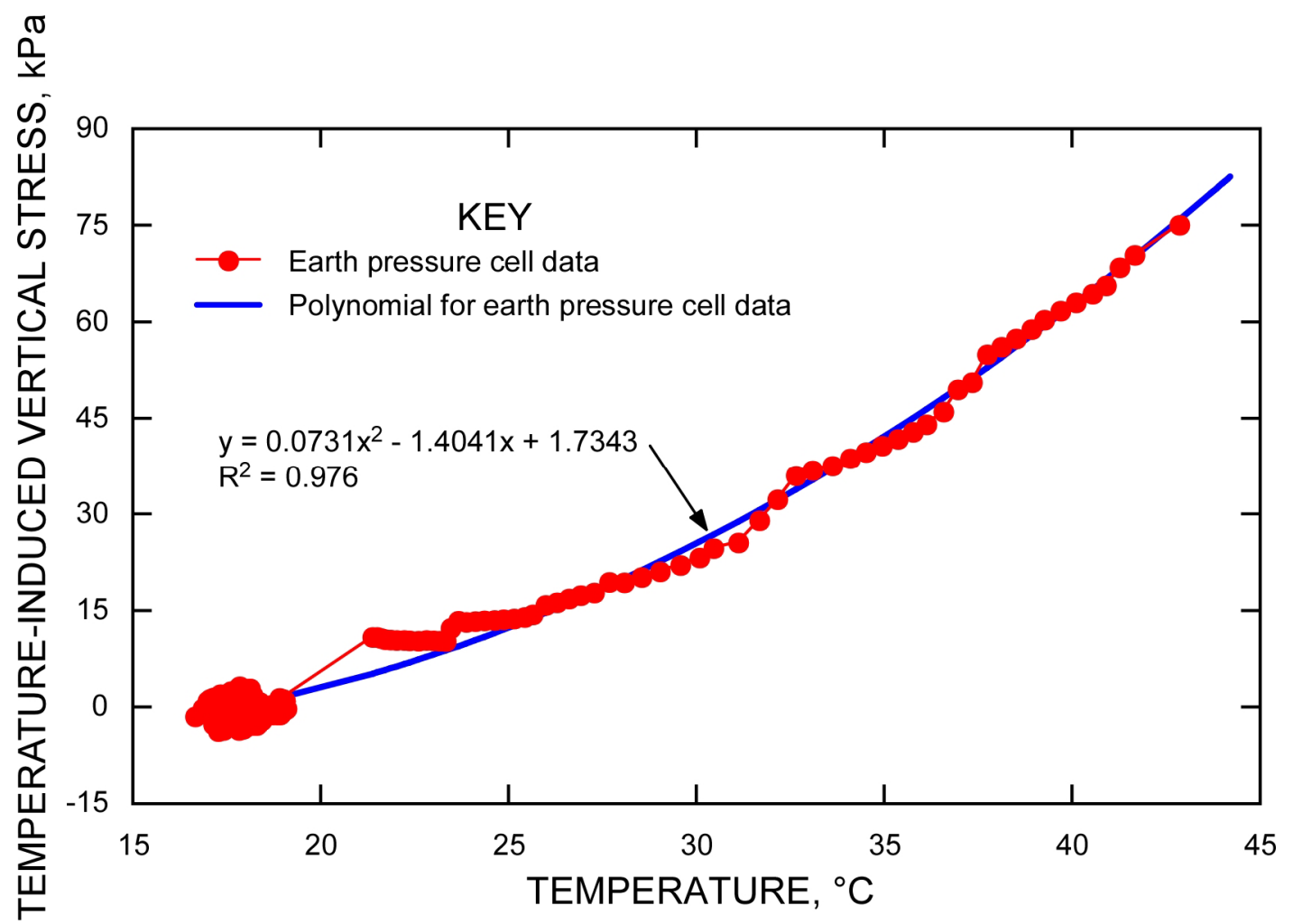

Figure A17.-Temperature-induced vertical stress versus temperature for earth pressure cell 3 at Foidel Creek Mine.

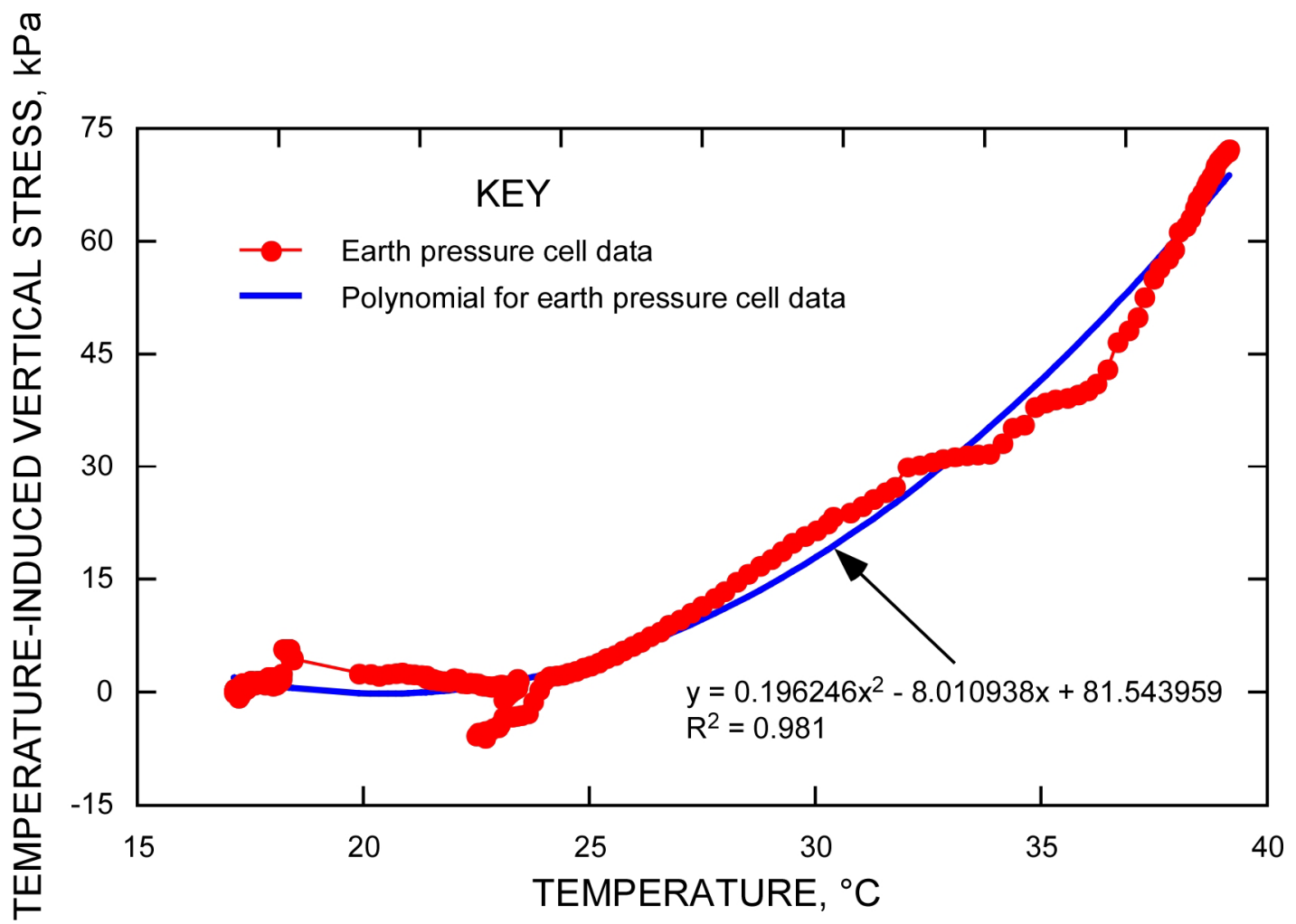

Figure A18.-Temperature-induced vertical stress versus temperature for earth pressure cell 4 at Foidel Creek Mine. 


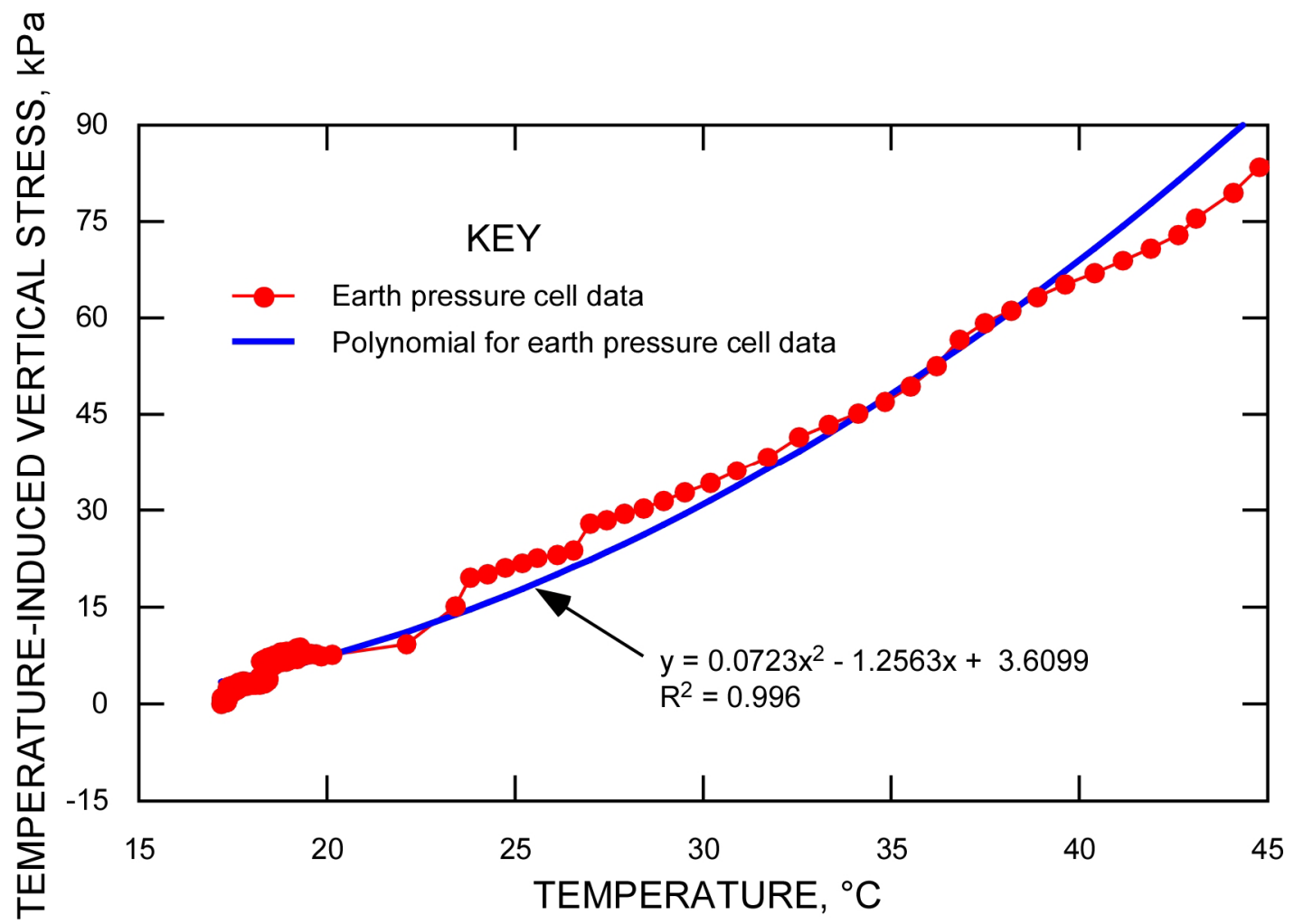

Figure A19.-Temperature-induced vertical stress versus temperature for earth pressure cell 5 at Foidel Creek Mine

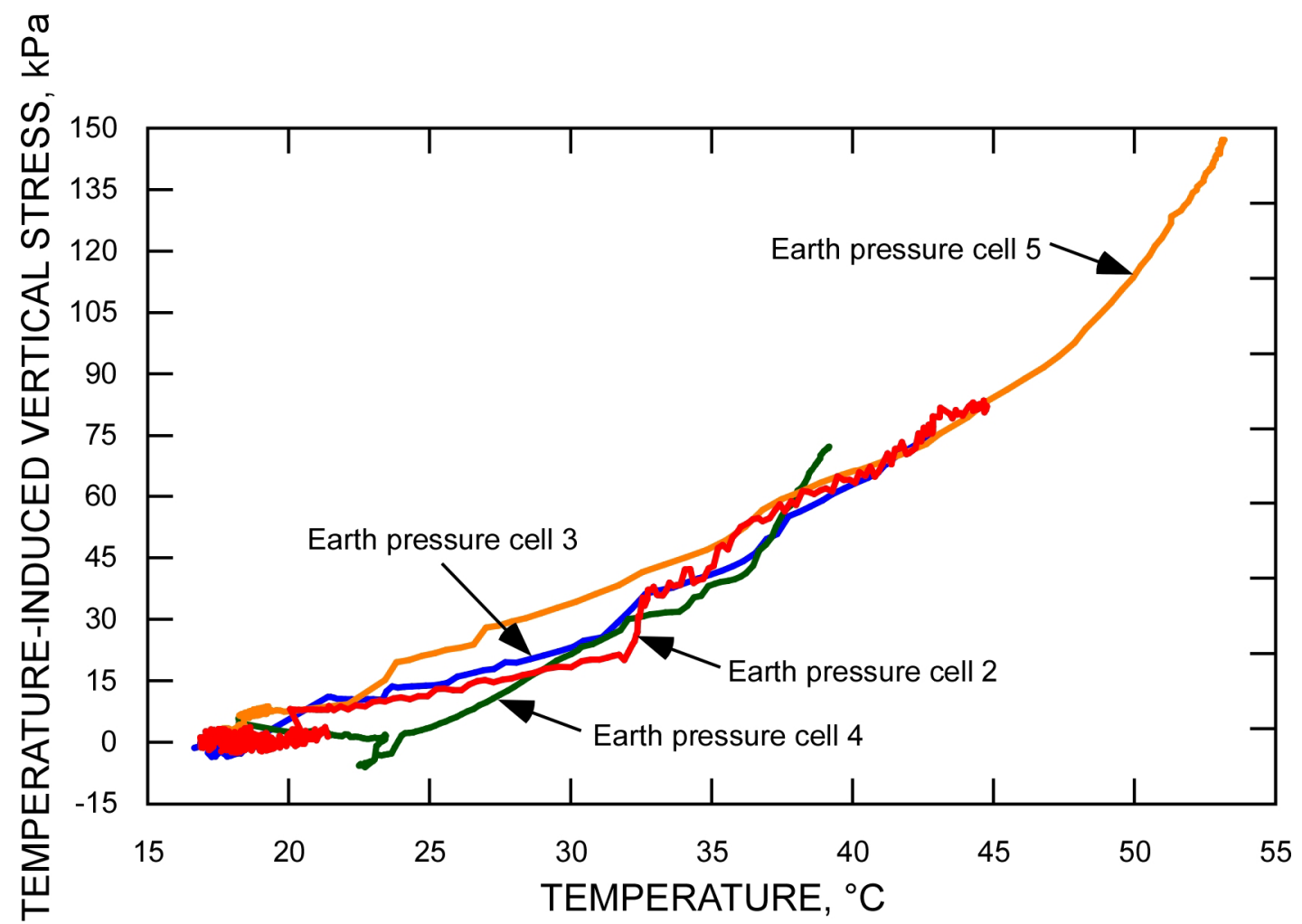

Figure A20.-Temperature-induced vertical stress versus temperature for earth pressure cells 2, 3, 4, and 5 at Foidel Creek Mine. 


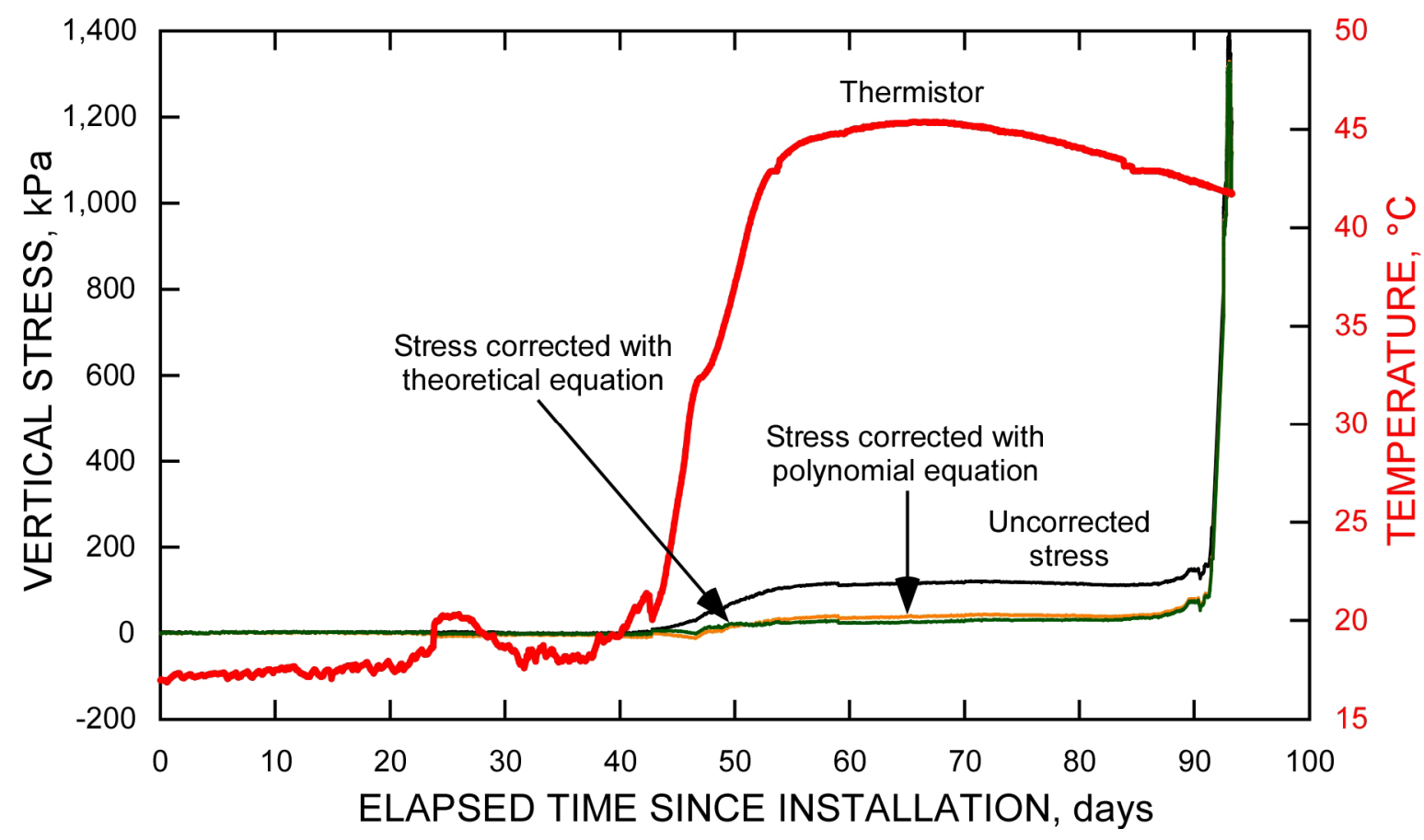

Figure A21.-Vertical stress and temperature versus elapsed time for earth pressure cell 2 at Foidel Creek Mine.

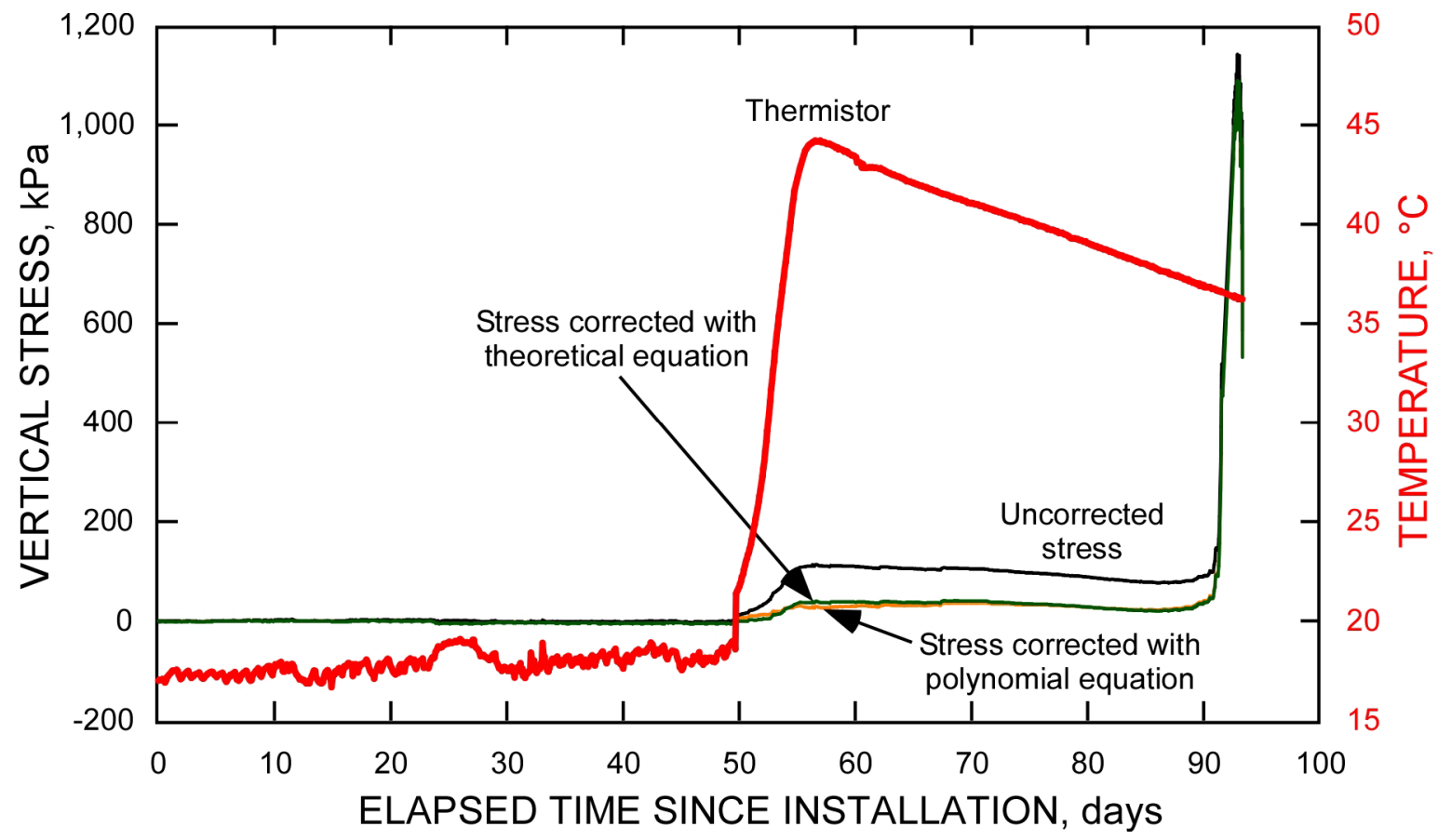

Figure A22.-Vertical stress and temperature versus elapsed time for earth pressure cell 3 at Foidel Creek Mine. 


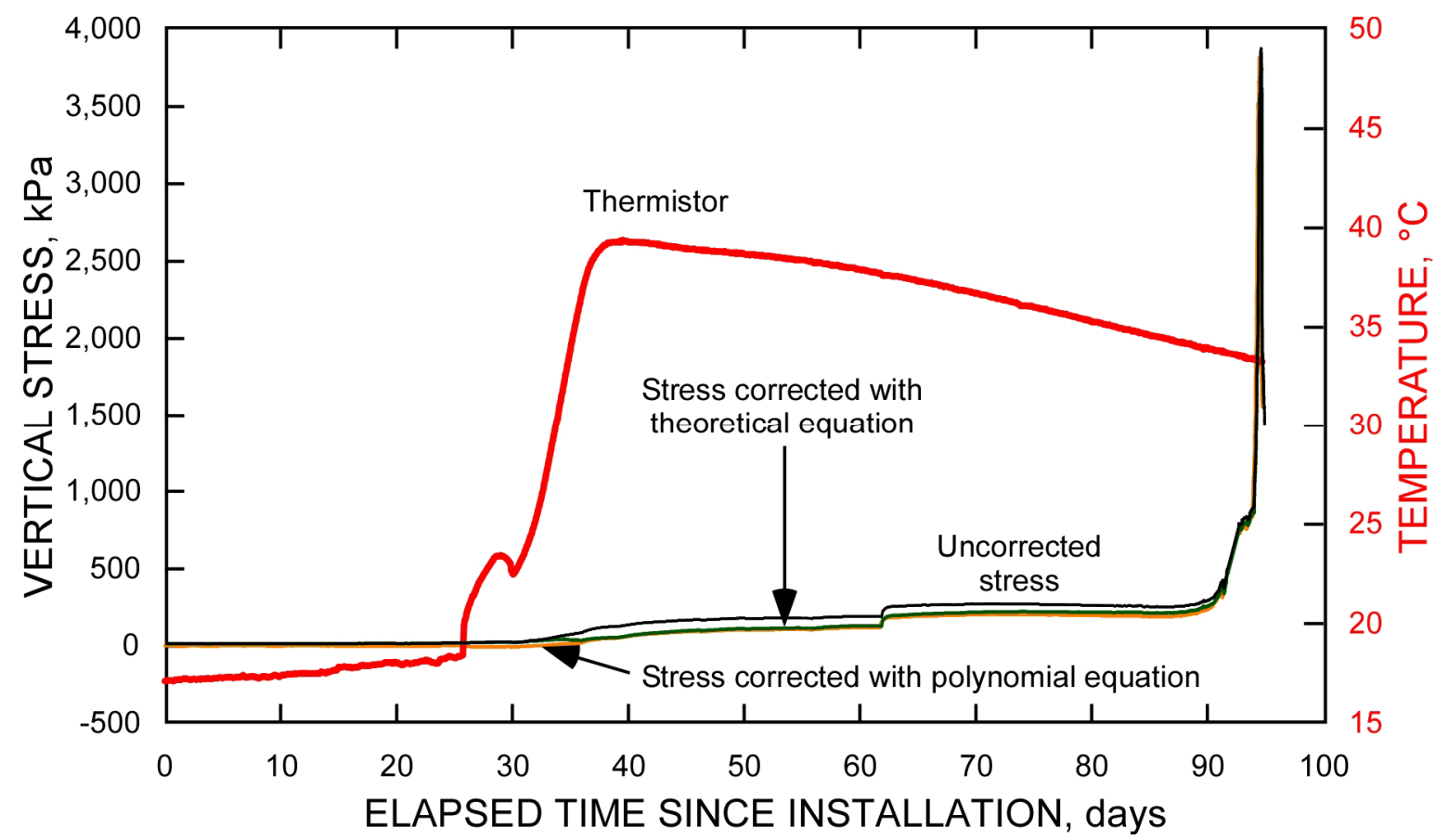

Figure A23.-Vertical stress and temperature versus elapsed time for earth pressure cell 4 at Foidel Creek Mine.

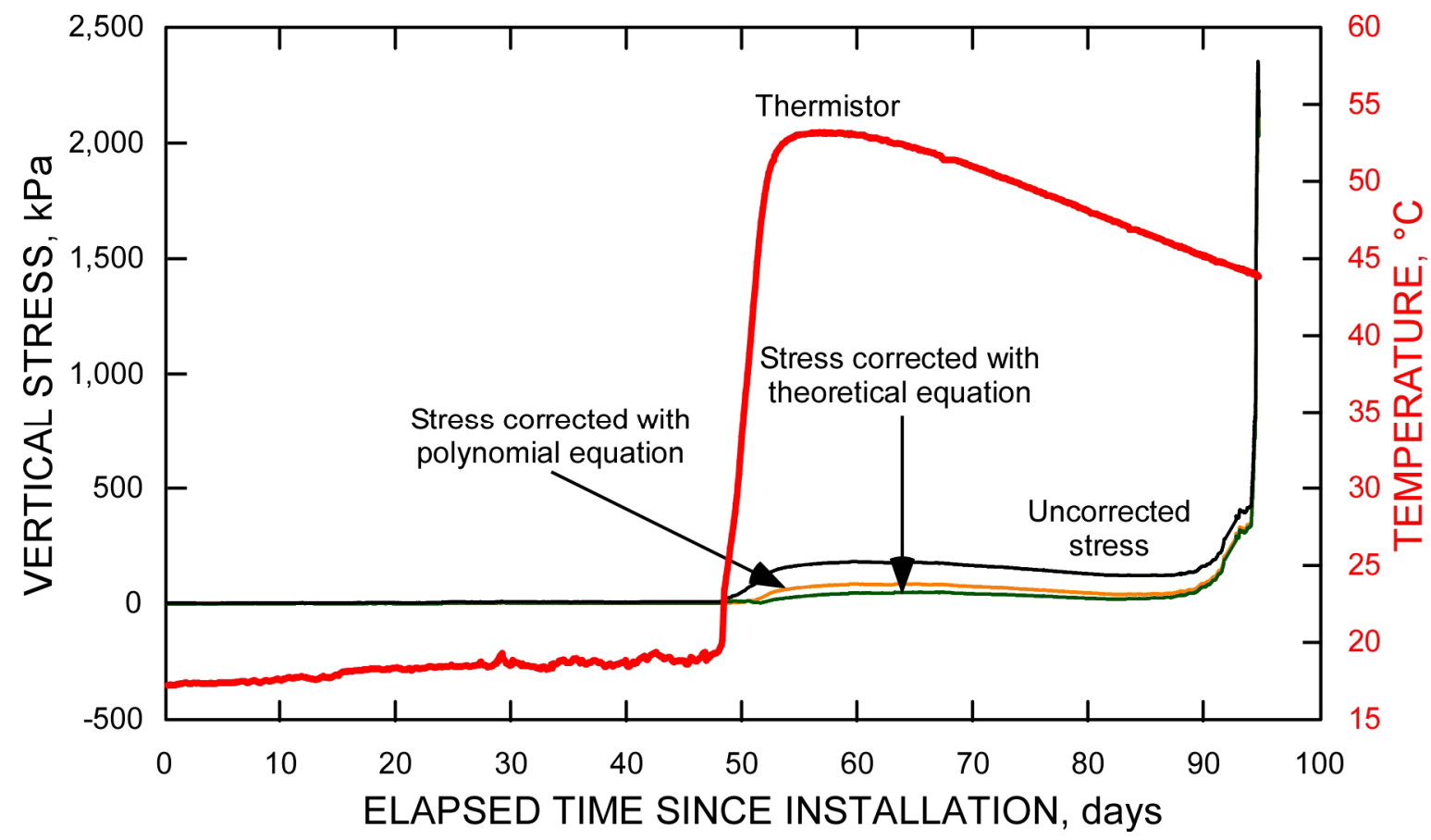

Figure A24.-Vertical stress and temperature versus elapsed time for earth pressure cell 5 at Foidel Creek Mine. 


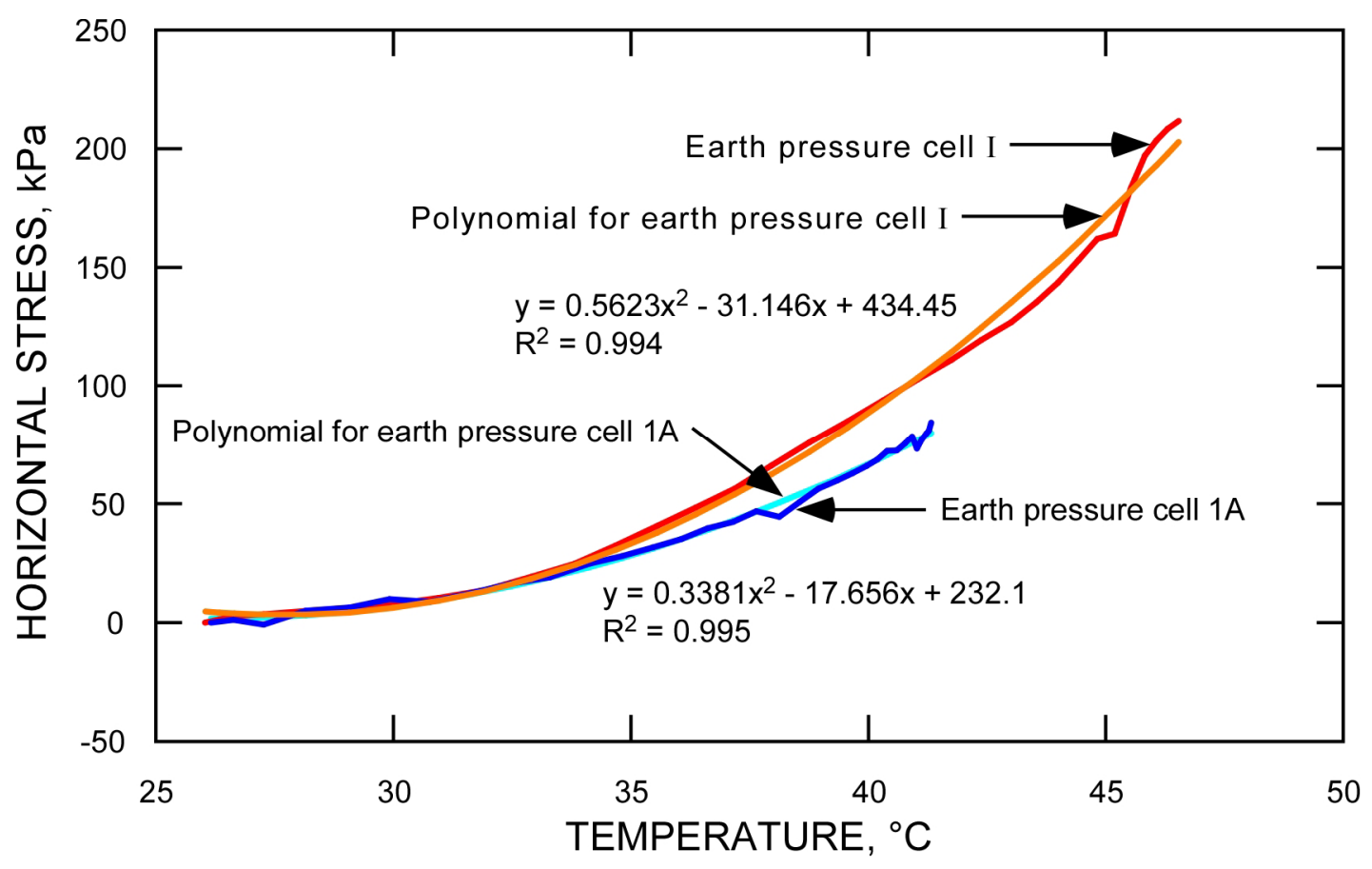

Figure A25.-Horizontal stress versus temperature in backfilled stope 5660-05 at Lucky Friday Mine.

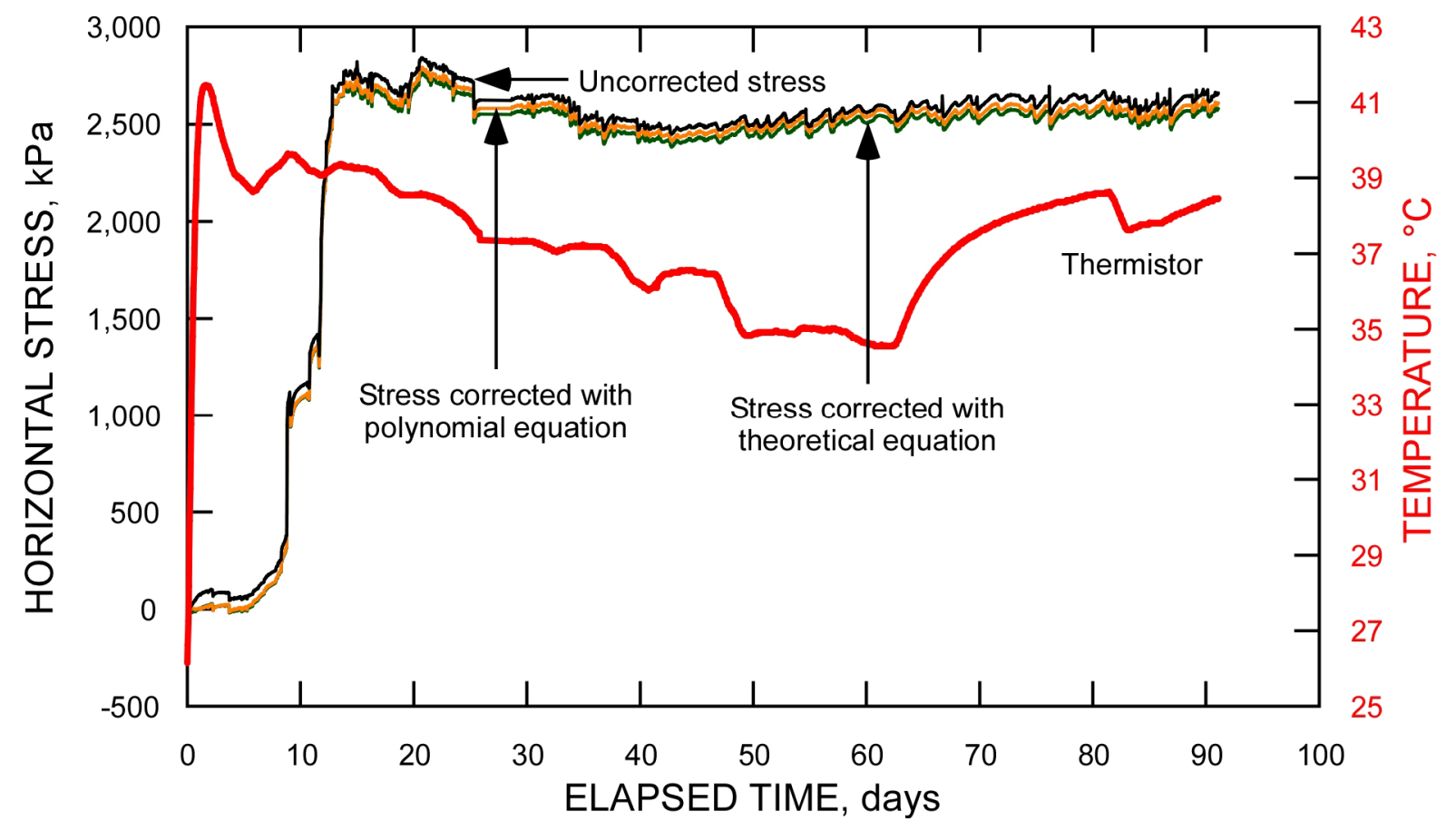

Figure A26.-Horizontal stress and temperature versus elapsed time for earth pressure cell $1 \mathrm{~A}$ in backfilled stope 5660-05 at Lucky Friday Mine. 


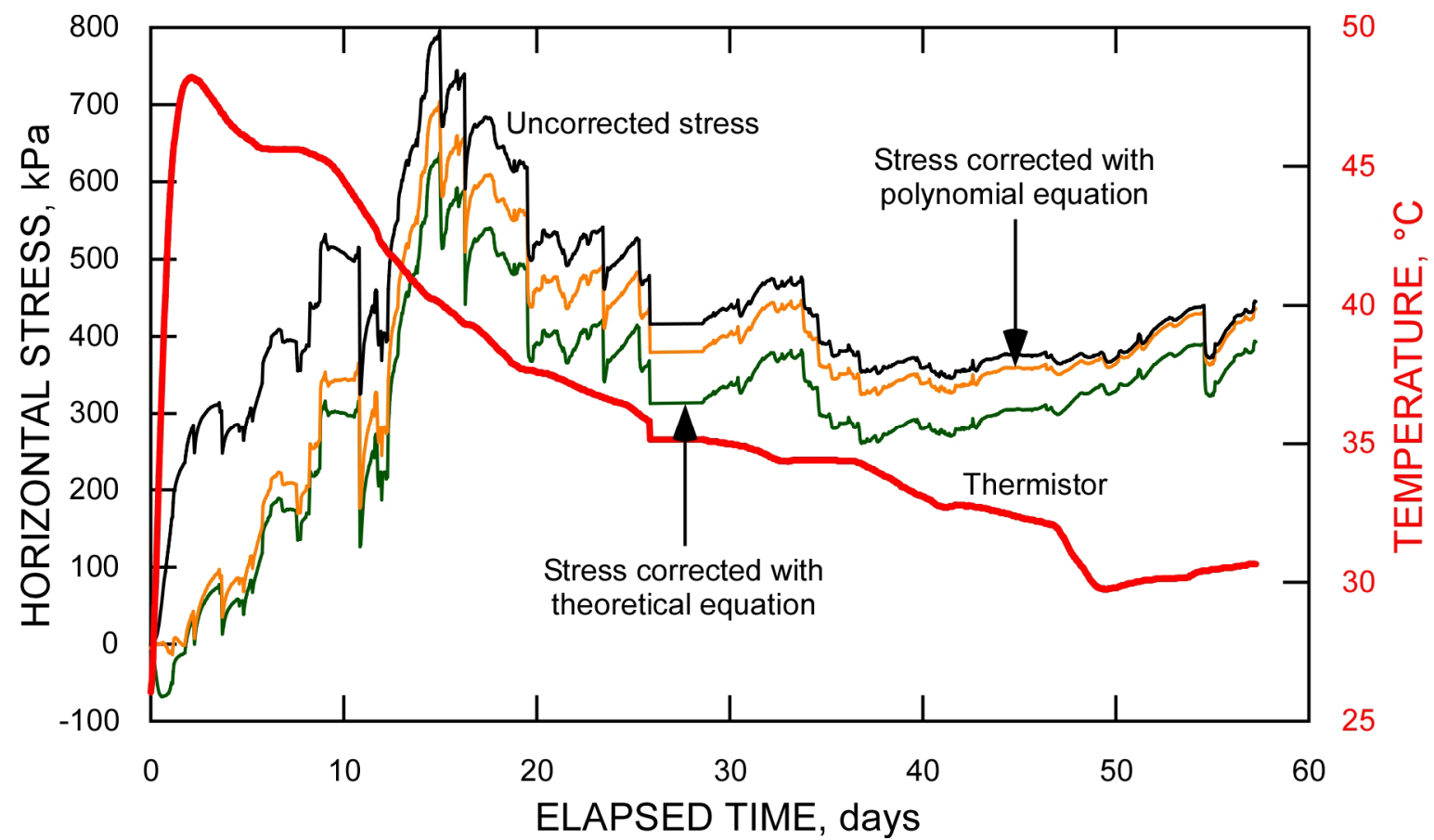

Figure A27.-Horizontal stress and temperature versus elapsed time for earth pressure cell I in backfilled stope 5660-05 at Lucky Friday Mine.

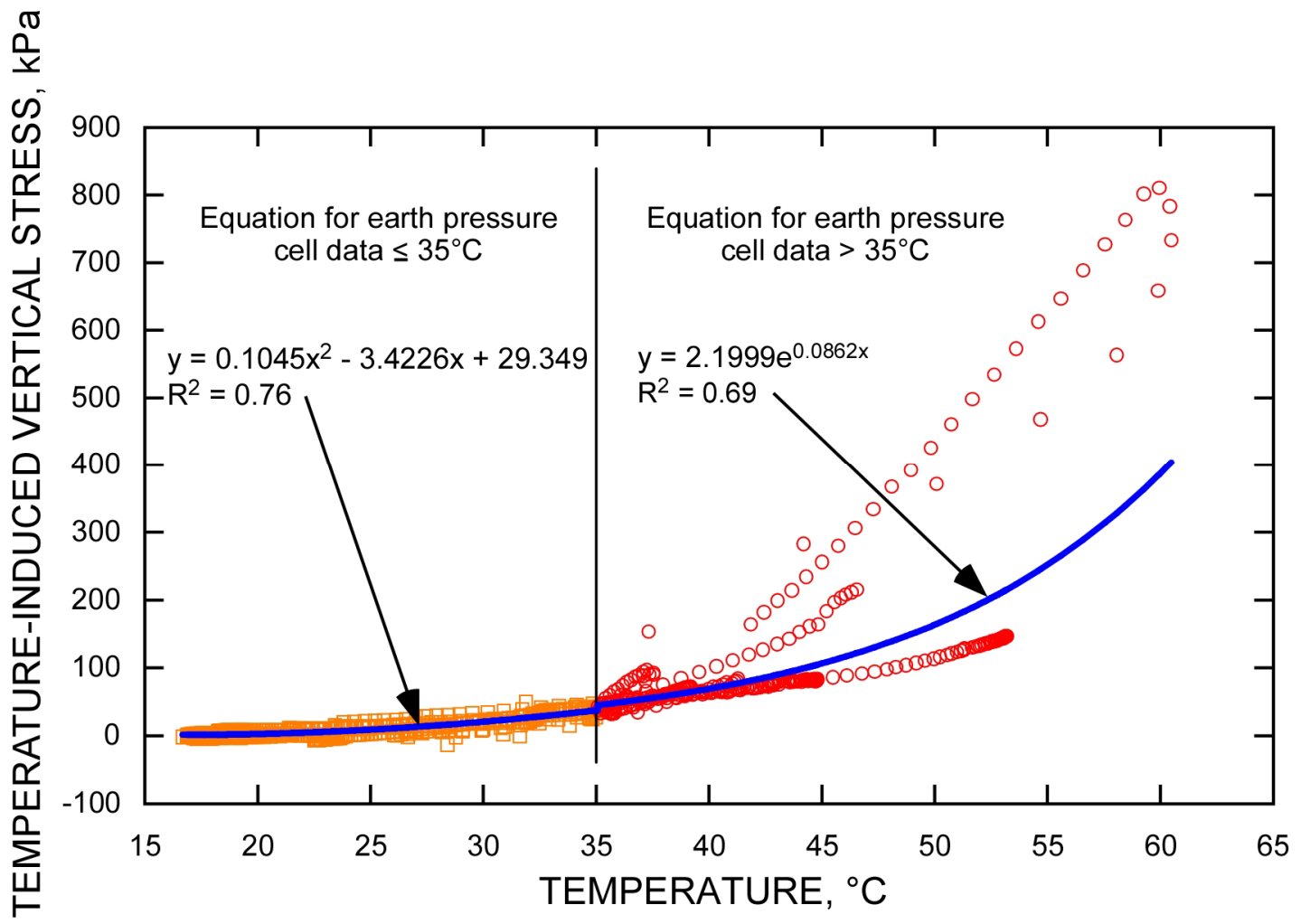

Figure A28.-Equations fit to temperature-induced vertical stress versus temperature for earth pressure cells installed at Turquoise Ridge, Foidel Creek, and Lucky Friday mines. 


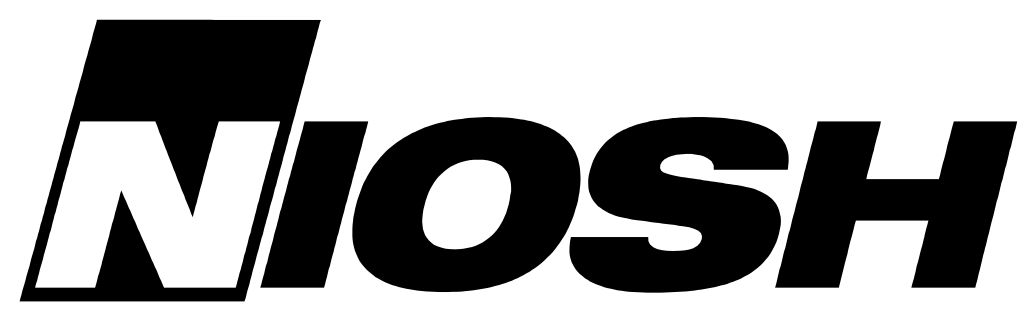

\title{
Delivering on the Nation's promise: Safety and health at work for all people Through research and prevention
}

To receive documents or more information about occupational safety and health topics, contact $\mathrm{NIOSH}$ at

\author{
1-800-35-NIOSH (1-800-356-4574) \\ FAX: $\quad 513-533-8573$ \\ e-mail pubstaft@cdc.gov
}

or visit the NIOSH Web site ot www.cdc.gov/niosh

\section{SAFER • HEALTHIER • PEOPLE ${ }^{\text {TM }}$}

DHHS (NIOSH) Publication No. 2006-103 